\title{
Cartografiar la destrucción. Los bombardeos de la Guerra Civil y el patrimonio inmueble de Madrid
}

\author{
Luis de Sobrón Martínez ${ }^{1}$ | Enrique Bordes Cabrera ${ }^{2}$ \\ Recibido: 08-11-2019 | en su versión final: 29-02-2020
}

Resumen

\begin{abstract}
En noviembre de 1936 da comienzo el primer bombardeo moderno sobre una gran ciudad europea: Madrid. Pese a la trascendencia de este acontecimiento, los bombardeos de Madrid quedaron posteriormente eclipsados. El objetivo del trabajo es elaborar una cartografía de la destrucción del patrimonio inmueble de Madrid a consecuencia de los bombardeos de la guerra, que permita profundizar en su análisis y conocimiento. Frente a los trabajos realizados sobre otras ciudades bombardeadas, entre las que destacan Guernica o Barcelona, llama la atención la falta de investigaciones específicas sobre los bombardeos de Madrid, los cuales sólo han sido estudiados en sus líneas generales, sin profundizar en las consecuencias que tuvieron para la ciudad. Las tres fuentes documentales principales tienen su origen en la actividad de tres colectivos profesionales: bomberos, fotorreporteros y arquitectos. De estas fuentes se ha seleccionado un conjunto de datos sobre aspectos relevantes de los ataques y sus efectos, como la sucesión diacrónica, el tipo de armamento empleado, la intensidad, los patrones o el grado de destrucción de los edificios. Una vez mapeados estos datos sobre la base cartográfica del catastro, se ha procedido a su análisis y expresión gráfica mediante el dibujo de la ciudad. El resultado del estudio es una base de datos mapeada en un conjunto de planos que podríamos denominar cartografía de la destrucción. En ellos se analizan y visualizan los diferentes parámetros estudiados, todos ellos relevantes para la comprensión de una realidad compleja sobre un soporte urbano, lo que permite profundizar en el conocimiento del urbicidio madrileño.
\end{abstract}

Palabras clave: visualización de datos; cartografía; urbicidio; memoria histórica

Citación

de Sobrón Martínez, L y Bordes Cabrera, E. (2020). Cartografiar la destrucción. Los bombardeos de la Guerra Civil y el patrimonio inmueble de Madrid. ACE: Architecture, City and Environment, 15(43), 9014. DOl: http://dx.doi.org/10.5821/ace.15.43.9014

Doctor arquitecto, Profesor Asociado, departamento de Ideación Gráfica Arquitectónica, E.T.S. de Arquitectura, UPM (ORCID: 0000-0003-0438-6572, WOS Researcher ID: S-2083-2016), ${ }^{2}$ Doctor arquitecto, Profesor Asociado, departamento de Ideación Gráfica Arquitectónica, E.T.S. de Arquitectura, UPM. (ORCID: 0000-0003-2373-4982). Correo de contacto: luis.desobron@upm.es 


\title{
Mapping the destruction. The Spanish Civil War bombings and Madrid's architectural heritage
}

Abstract

\begin{abstract}
In November 1936 began the first modern bombing of a great European city: Madrid. Despite the importance of this event, the bombings of Madrid were subsequently forgotten. The aim of this work is to carry out a cartography of the buildings destruction of Madrid as a result of the bombings of the war, in order to deepen its analysis and knowledge. Unlike other bombed cities have been the subject of study, among which Guernica or Barcelona stand out, the lack of specific research on the bombings of Madrid is striking. These have only been broadly studied, without delving into the consequences they had for the city. The three main documentary sources have their origin in the activity of three professional groups: firefighters, photojournalists and architects. From these sources, we have selected a set of data on relevant aspects of the attacks and their effects, such as diachronic succession, type of bombs thrown, intensity, patterns and degree of destruction of the buildings. Once these data have been mapped on the cartographic basis of the cadastral plan, we have graphically analysed and graphically expressed the information. The main result of the research is a database mapped on a set of city plans that we could call destruction cartography. They allow to analyse and visualise the different parameters studied, all of them relevant for the understanding of a complex reality on an urban support, which allows to deepen the knowledge of Madrid urbicide.
\end{abstract}

Keywords: data visualization; mapping; urbicide; historical memory

\section{Introducción: El Guernica era Madrid}

En noviembre de 1936 se sucedieron tres semanas durante las cuales la Legión Cóndor de la Alemania nazi y la Aviazione Legionaria de la Italia fascista bombardearon Madrid sistemáticamente y casi sin interrupción. Simultáneamente comenzaron los bombardeos artilleros desde las posiciones de las tropas sublevadas contra la República, que prácticamente cercaban la ciudad, y que no cesaron hasta febrero de 1939, poco antes de la rendición de la ciudad y del fin de la contienda.

No era ésta la primera ocasión en que se atacaba desde el aire a una población civil. Todas las metrópolis occidentales habían llevado a la práctica esta forma de mantener el orden entre la población nativa de sus respectivas colonias: Italia en Libia y Etiopía; Francia en Marruecos y Siria; España también en Marruecos; Estados Unidos en Nicaragua; Gran Bretaña en Somalia, Egipto, India, Afganistán, Irak, etc. (Lindqvist, 2002).

Tampoco era Madrid la primera población europea sobre la que se arrojaban bombas. Durante la Primera Guerra Mundial Londres sufrió varios ataques aéreos que costaron la vida de aproximadamente 1.400 ciudadanos. No obstante, estos ataques tuvieron un carácter esporádico y experimental y no llegaron a jugar un papel importante en la estrategia militar de una guerra que se libró fundamentalmente en los campos de batalla (Lindqvist, 2002).

ACE, 15 (43) CC BY-ND 3.0 ES | UPC Barcelona, España | Cartografiar la destrucción. Los bombardeos de la Guerra Civil y el patrimonio inmueble de Madrid. DOI: http://dx.doi.org/10.5821/ace.15.43.9014 
Por otro lado, a pesar de que el bombardeo de Madrid adquirió inicialmente gran celebridad en la prensa extranjera, pocos años después quedaría eclipsado por la fama de los de otras urbes como Guernica, Barcelona, Varsovia, Rotterdam, Coventry, Liverpool, Londres, Hamburgo, Colonia, Berlín o Dresde, por mencionar sólo algunas de las principales poblaciones europeas bombardeadas. De hecho, raramente se menciona el caso de Madrid cuando de ciudades bombardeadas se trata.

No obstante, Madrid es la primera gran ciudad europea en la que se puso en práctica un bombardeo sistemático con tecnología moderna como elemento fundamental de la estrategia militar, como método para lograr la rendición del enemigo mediante el terror y la desmoralización de su población?. Esta categórica afirmación no es sólo una deducción que, ochenta años después, podamos plantear a partir de las consideraciones que se desgranan en los siguientes párrafos, y que podamos corroborar a partir de los resultados mismos de esta investigación, sino que, ya en el momento de producirse los acontecimientos existía la percepción de tratarse de unos hechos sin precedentes: "Por primera vez en la historia, una población civil sufrió todo el horror de la guerra moderna." (Clavet, 1937, 68).

En Madrid, por primera vez se ponen en práctica las teorías militares de Giulio Douhet y Liddell Hart sobre una ciudad de más de un millón de habitantes. Douhet defendió, desde sus primeros años en el escuadrón aéreo de Turín, que la tecnología aeronáutica estaba destinada a convertir el bombardeo aéreo en la principal forma de ataque, eliminando la distinción entre combatientes y civiles, tanto por el hecho de que, desde el aire, se difuminan los límites entre el frente y la retaguardia, como por la naturaleza de los bombardeos aéreos, cuya precisión, o más bien su falta, obliga a pensar en objetivos zonales en vez de puntuales. En Il dominio dell'aria (1921), su principal obra teórica, justificaba la brutalidad de los bombardeos sobre poblaciones con la premisa de que un ataque rápido y contundente siempre causaría menos daños que una guerra prolongada². Por su parte, el estratega militar británico Liddell Hart proponía en París o el futuro de la guerra (1925) "trastornar su vida normal hasta tal punto que prefiera el mal menor que supone la rendición” (Lindqvist, 2002, pág. 124), refiriéndose, naturalmente, al enemigo.

Este es el contexto en el que hay que situar el reconocimiento del general Alfredo Kindelán, jefe de los Servicios del Aire de las fuerzas sublevadas, cuando afirma: "por aquellos días, cuando Franco ordenó un ensayo de actuación desmoralizadora de la población mediante bombardeos aéreos..." (Kindelán, 1982, 91). Desde el principio se evidenció el fracaso de esta táctica, ya que "más que desmoralizarla (a la población), contribuyeron a enfurecerla y lograron que una gran masa, indiferente al principio, odiara a la causa nacionalista" (Solé y Villarroya, 2003, pág. 48).

No obstante, hubo también otros objetivos. Madrid, junto con muchas otras poblaciones españolas, fue también un escenario de puesta a punto y entrenamiento con fuego real para pilotos y militares de la Legión Cóndor: “La Legión Cóndor era un grupo aéreo, totalmente autónomo, constituido para poner a prueba la eficacia del material bélico aéreo alemán en condiciones reales de combate y ensayar las diversas teorías sobre el empleo del poder aéreo y sobre el apoyo táctico a las fuerzas de superficie. Para el gobierno alemán, la Guerra Civil Española no era otra cosa que una escuela de adiestramiento para los pilotos de la Luftwaffe." (De Vicente, 2014a, pág. 50).

Finalmente, numerosas poblaciones españolas sirvieron como laboratorio de ensayo de la eficacia de las nuevas tácticas militares y de la capacidad destructiva de la nueva tecnología armamentística alemana: "se produjeron varias y notables innovaciones operativas como los bombardeos incendiarios, los nocturnos, los rasantes, en cadena y sin motor” (De Vicente, 2014a, pág. 499). Este sería el ensayo general de una representación final que, poco tiempo después y a mayor escala aún,

\footnotetext{
1 "Civilians had been the casualties of air bombardments prior to the Spanish Civil War, but nothing on the scale of the attacks on Madrid had been inflicted on a major European city" (Minchom, 2015, pág. 98).

2 // dominio del/'aria fue traducido al alemán en 1935.
}

ACE, 15 (43) CC BY-ND 3.0 ES | UPC Barcelona, España | Cartografiar la destrucción. Los bombardeos de la Guerra Civil

y el patrimonio inmueble de Madrid. DOI: http://dx.doi.org/10.5821/ace.15.43.9014 
dio comienzo con un primer acto en Varsovia y se prolongó en una larga lista de ciudades europeas (Solé y Villarroya, 2003).

Todas estas consideraciones justifican por sí mismas un estudio en profundidad del urbicidio ${ }^{3}$ de Madrid, que todavía no se ha llevado a cabo. Según Minchom (2010), las imágenes que Picasso empleó en el célebre cuadro que convirtió el bombardeo de Guernica en icono del nuevo paradigma bélico, tienen su origen en las crónicas escritas por Louis Delaprée, de las escenas que vivió durante los bombardeos en Madrid. Paradójicamente, el Guernica era Madrid.

\section{Objetivo: Visualizar la destrucción frente a la abstracción del dato}

El objetivo principal de esta investigación es la representación cartográfica, para su posterior análisis, de la destrucción del patrimonio urbano y arquitectónico de Madrid durante la Guerra Civil Española a consecuencia del que podemos considerar como el primer bombardeo contemporáneo sobre una gran ciudad. Se trata, por tanto, no sólo de alcanzar un conocimiento profundo, a través del análisis gráfico, sobre el cómo, el cuándo y el dónde de los sucesos objeto de estudio, sino también de comunicar y facilitar la comprensión de dichos sucesos, que se antojan complejos, y que tuvieron lugar sobre un soporte también complejo como es la ciudad, a través de un instrumento idóneo para ello: el dibujo. "El Dibujo puede ser pues el elemento esencial de sistematización metodológica de un proceso de investigación y su expresión material de conclusiones. Esta afirmación se vuelve categórica cuando lo que está implicado en el objeto de estudio es la forma arquitectónica" (Martínez y Muñoz, 2016, pág. 1067). Cabría parafrasear la cita, por extensión, diciendo cuando lo que está implicado en el objeto de estudio es la forma arquitectónica y urbana.

Evidentemente, la primera consecuencia de esta táctica de guerra, y la más trágica, son las víctimas personales, directas e indirectas. Los muertos, los heridos y el estrés psicológico de una población sometida a constantes situaciones de peligro y al impacto visual y sonoro de las bombas y de sus efectos $^{4}$, son aspectos difíciles de cuantificar (Minchom, 2015) que conducen fácilmente a guerras de cifras. Más aún en un campo de estudio como el de la Guerra Civil Española en el que, ochenta años después, aún persisten no pocas artificiosas controversias basadas más en interpretaciones ideológicas que en hechos contrastados. Esta investigación, sin embargo, se centra en la destrucción del patrimonio material inmueble de Madrid, un aspecto más tangible de los bombardeos sobre las ciudades. Probablemente el aspecto más reproducido en imágenes y, por ello, aparentemente uno de los mejor conocidos de las guerras contemporáneas.

\footnotetext{
${ }^{3}$ El término urbicidio no figura en el diccionario de la Real Academia Española de la Lengua, aunque es muy expresivo dada su analogía con otros, como genocidio, suicidio, parricidio, etc. Etimológicamente deriva de los términos latinos urbs (ciudad) y caedere (matar), por lo que podemos entenderlo literalmente como "asesinato de la ciudad" o, menos figuradamente, como "destrucción de la ciudad". En su origen fue acuñado en 1963 por el escritor Michael Moorcock, en su novela "Elric: Dead God's Homecoming", y empleado durante las décadas de 1960 y 1970 por autores como Huxtable o Berman en referencia a la destrucción de determinadas áreas urbanas como resultado de las reestructuraciones urbanas en ciudades norteamericanas (Coward, 2009). Posteriormente, a raíz de los bombardeos de ciudades como Sarajevo o Mostar durante la guerra de Yugoslavia, fue empleado por Ribarevic-Nikolic y Juric (1992), reivindicando el término urbicidio como expresión de una categoría específica bajo la que habría que considerar el fenómeno de la destrucción del entorno construido. Más recientemente. Coward (2009) propone como definición de urbicidio la deliberada destrucción de edificios, entendidos como condición que posibilita una cualidad existencial urbana específica: la heterogeneidad. Recientemente, con motivo de la destrucción de ciudades como Homs o Alepo, en la guerra de Siria, el término ha vuelto a cobrar relevancia. Aunque cuantitativamente la destrucción sufrida por Madrid durante la Guerra Civil Española no es comparable a la de las ciudades referidas, es el hecho de considerar la destrucción por medios militares de la población como un objetivo en sí mismo lo que justifica la utilización del término en el presente estudio. Máxime considerando, declaraciones como las del general Franco a los corresponsales extranjeros, que publicaba The Times el 12 de noviembre de 1936, durante los bombardeos de la ciudad: "Destruiré Madrid antes que dejárselo a los marxistas" (Solé y Villarroya, 2003, pág. 47); o telegramas como el de la embajada francesa en Madrid del 19 de noviembre de 1936: "El bombardeo de la capital ha continuado sin parar durante 24 horas, lo que sugiere que los rebeldes quieren destruir Madrid" (Minchom, 2015, pág. 111, traducción de los autores). 4 "Cuando se corre peligro de muerte se tiene miedo: antes, en el momento o después...Aquellos días del mes de noviembre de 1936 todos y cada uno de los habitantes de Madrid estaban en constante peligro de muerte...La granada que mató a la vendedora de periódicos de la esquina de la Telefónica lanzó una de sus piernas al centro de la calle, lejos del cuerpo..." (Barea, 1977, pág. 219).
} 
La bibliografía existente sobre bombardeos de ciudades es abundante, aunque, en el caso de las ciudades españolas, la mayoría de los trabajos han sido publicados en este siglo, indicio de un creciente interés en un aspecto de nuestra historia reciente insuficientemente estudiado con anterioridad. En el caso de Madrid destacan tres trabajos: el de Solé y Villarroya (2003), que fue el primer estudio en profundidad realizado sobre el uso de la aviación en la Guerra Civil y sobre los bombardeos sufridos por las poblaciones españolas; el de De Vicente (2014a), quien, en su trilogía sobre la historia militar de la Guerra Civil en Madrid, dedica un volumen a la exposición ordenada de una gran cantidad de información sobre los bombardeos y sus consecuencias, resultado de un arduo trabajo de documentación, principalmente en archivos militares españoles; y el de Andrés (2017), centrado en la destrucción del patrimonio arquitectónico histórico-artístico, especialmente del eclesiástico, durante la II República Española y la guerra. Además de estos hay otros estudios parciales entre los que se enumeran, sin ánimo de ser exhaustivos, los de Morcillo (2011), Blasco y Goitia (2014) y Moreno-Aurioles (2016). Además de estos estudios, referidos al caso de Madrid, no se puede dejar de citar, en la medida en que han servido también como referente de esta investigación, los trabajos de Albertí (2004) y de Arañó y Capdevila (2018) sobre los bombardeos de Barcelona. Estos últimos aportan material gráfico que permite una lectura visual del discurso de la investigación.

Efectivamente, los trabajos historiográficos suelen ser literariamente muy descriptivos y abundar en cifras, pese a lo cual no siempre facilitan una comprensión rápida, global y comparativa de las consecuencias materiales de los bombardeos sobre nuestras ciudades. Algunos de los trabajos pioneros en el camino de la comprensión visual de las consecuencias de los bombardeos sobre el soporte físico de nuestras ciudades son los de Halley Docherty, Javier Marquerie y Sebastian Maharg. La primera experimenta superponiendo imágenes de escenas de la primera y segunda guerras mundiales sobre una imagen de fondo actual de los mismos lugares donde se desarrollaron aquellas escenas (Figura 1). Marquerie ${ }^{5}$ y Maharg $^{6}$ han llevado a cabo trabajos fotográficos, partiendo de un planteamiento similar, con escenas de la Guerra Civil en Madrid. La capacidad comunicativa de estas imágenes, eliminando la dimensión temporal mediante la superposición del espacio pasado al espacio actual, es indudable.

Figura 1. Fotomontajes de Docherty para las series I WW y II WW in Google Street View
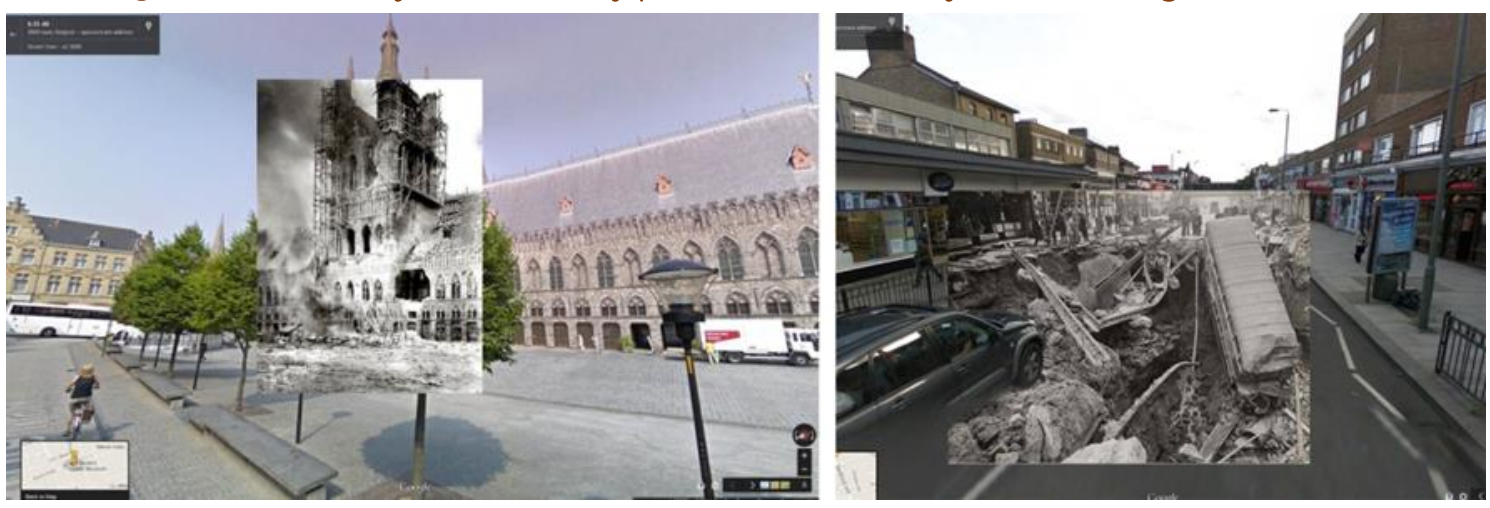

Izquierda: Las ruinas de Lakenhalle en Ypres, Bélgica, 1914. Fuente: The Guardian (Docherty, 2014b). Derecha: Refugio antiaéreo de Balham station parcialmente destruido por una bomba. Londres, 1940. Fuente: The Guardian (Docherty, 2014b)

Sin embargo, a pesar de la inmediatez icónica de la fotografía, que permite una aproximación al conocimiento de los hechos, estas imágenes no suelen facilitar una comprensión global y profunda del grado y extensión de los daños producidos en el patrimonio inmueble de una ciudad. La mayoría son, como señala De las Heras, imágenes parciales: "El primer paso es entender que la fotografía no

\footnotetext{
5 Serie de fotografías Madrid, iqué bien resistes!, 2013.

${ }^{6}$ https://www.sebastianmaharg.com/madrid-1936-1939
}

ACE, 15 (43) CC BY-ND 3.0 ES | UPC Barcelona, España | Cartografiar la destrucción. Los bombardeos de la Guerra Civil

y el patrimonio inmueble de Madrid. DOI: http://dx.doi.org/10.5821/ace.15.43.9014 


\section{ACE Architecture, City and Environment}

muestra la realidad. En todo caso, muestra realidades. Si creemos que la fotografía es un espejo de la realidad erramos pues en ella se muestra lo que el operador de cámara, bajo su criterio o influido por un comitente, quiere mostrar en el instante en que encuadra (atendiendo a motivaciones de orden estético, cultural, ideológico o político) y apartando otras muchas posibilidades que se presentan como realidades veladas al lector pero que pueden dejar su huella en la instantánea." (De las Heras, 2014, págs. 344-345).

Incluso cuando se trata de imágenes del conjunto urbano, como es el caso de las fotografías aéreas de los ataques (Figura 2), por sí solas adolecen de la falta de un criterio interpretativo y del procesamiento de la información necesario para una fácil y completa comprensión del alcance de los hechos que retratan. Cartografiar la destrucción no debe limitarse a ubicar impactos sobre un plano urbano, sino que debe interpretar los datos y facilitar la comprensión de una realidad compleja. Una cartografía de la destrucción debe aportar una lectura coherente de los hechos constatados y evidenciar visualmente parámetros reveladores, como cronología, extensión, intensidad, patrones y relaciones que no se perciben en una mera enumeración y localización geográfica de datos. Existen pocos trabajos que, a partir de estas consideraciones, recurran específicamente a medios gráficos para investigar y difundir el conocimiento y la comprensión global y detallada al mismo tiempo de la destrucción de ciudades bombardeadas.

Figura 2. Bombardeo aéreo de Barcelona el 17 de marzo de 1938

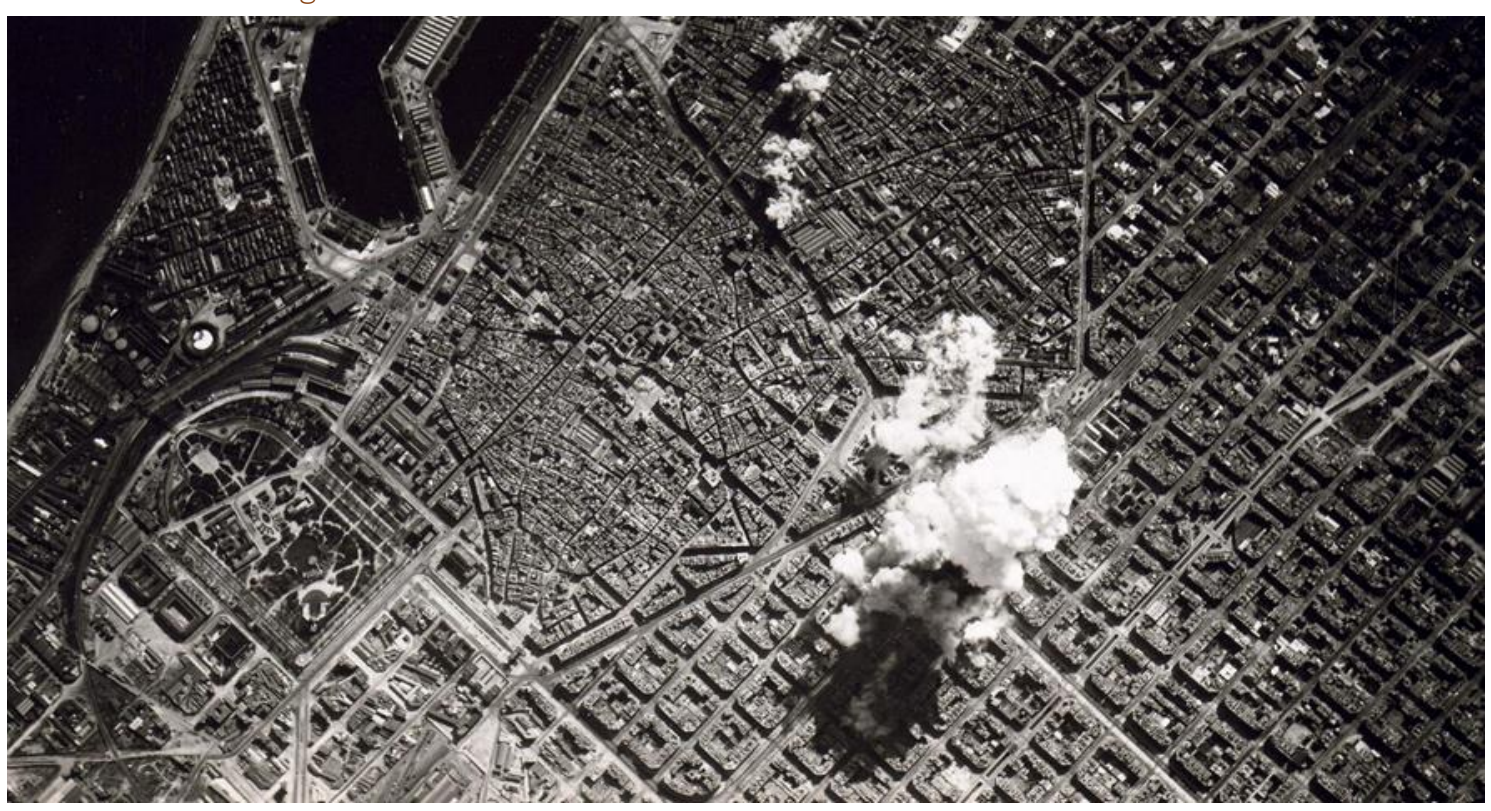

Fuente: Fuerzas aéreas de Italia. Recuperado de https://commons. wikimedia.org/w/index.php?curid=25495577

Antecedentes de cartografías de bombardeos de ciudades los encontramos ya en el siglo XIX y, en concreto, uno referido a la misma ciudad objeto de análisis de esta investigación. Se trata del plano trazado en 1809 por el ingeniero geógrafo Bentabole para representar el bombardeo de la ciudad por la artillería de Napoleón (Figura 3). No obstante, la finalidad de este documento no es tanto historiográfica como conmemorativa (Quirós y Castañón, 2008). En él, sobre un plano de Madrid y su entorno próximo, se representan las posiciones de las tropas y de las baterías de artillería francesas, la trayectoria de los proyectiles y los lugares de los impactos. Tras la I Guerra Mundial se dibujaron planos con los impactos de los bombardeos aéreos austriacos de algunas ciudades italianas como Venecia o Treviso.

ACE, 15 (43) CC BY-ND 3.0 ES | UPC Barcelona, España | Cartografiar la destrucción. Los bombardeos de la Guerra Civil

y el patrimonio inmueble de Madrid. DOI: http://dx.doi.org/10.5821/ace.15.43.9014 


\section{ACE Architecture, City and Environment}

Figura 3. Bentabole, Joseph Charles Marie. Plan de Madrid et de ses environs (detalle). E 1:20.000

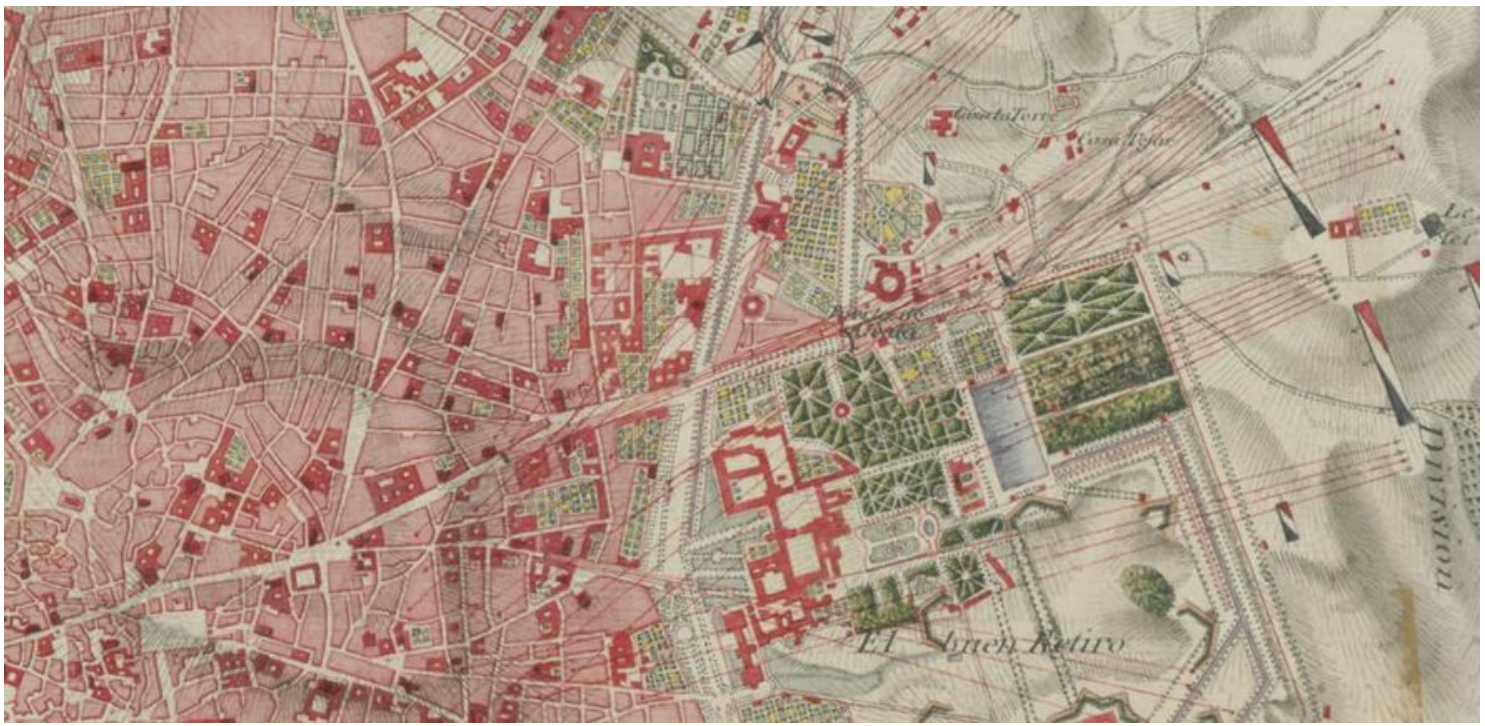

Fuente: Service Historique de la Défense, Département de l’Armée de Terre, Section de Archives Techniques, Francia.

Otro notable referente, de nuevo sobre la ciudad de Madrid, es el trabajo desarrollado por el Comité de Reforma, Reconstrucción y Saneamiento de Madrid (CRRSM, 1938) durante el transcurso de la Guerra Civil. Un trabajo sobre el que incidiremos más adelante, puesto que constituye una de las principales fuentes documentales de la investigación. La documentación gráfica elaborada por el CRRSM es el antecedente inmediato del Bomb Census y de los Bomb Damage Maps londinenses, elaborados en Reino Unido durante la Segunda Guerra Mundial. El Bomb Census fue un procedimiento de recopilación de información, después de cada ataque aéreo, para la elaboración posterior de planos donde se reflejó, con código de colores, la intensidad de los daños causados en los edificios (Figura 4). El propósito era "dotar al gobierno de un mapa completo de los patrones de ataque aéreos, tipos de armas usadas y daños causados, particularmente en servicios estratégicos e instalaciones"7. Después de la Segunda Guerra Mundial se elaboraron planos de otras ciudades europeas afectadas por los bombardeos como Coventry, Birmingham o Berlín.

Figura 4. Bomb damage maps, elaborados por el London County Council entre 1939 y 1945
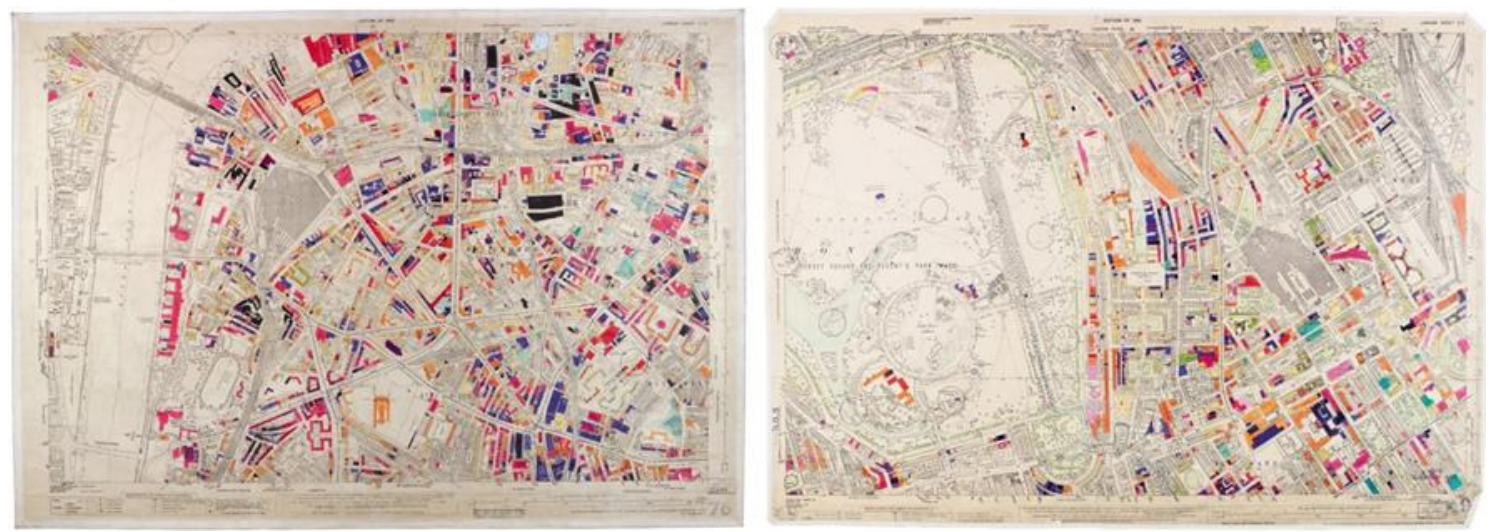

Fuente: London Metropolitan Archives. Recuperado de https://www.citylab.com/design/2016/05/london-bombdamage-maps-blitz/481350/

${ }^{7}$ http://www.nationalarchives.gov.uk/help-with-your-research/research-guides/bomb-census-survey-records-1940-1945/

ACE, 15 (43) CC BY-ND 3.0 ES | UPC Barcelona, España | Cartografiar la destrucción. Los bombardeos de la Guerra Civil

y el patrimonio inmueble de Madrid. DOI: http://dx.doi.org/10.5821/ace.15.43.9014 


\section{ACE Architecture, City and Environment}

Más recientemente, algunos de los planos del Bomb Damage Maps han sido la base documental del Bomb Sight Projects. Este proyecto, dirigido por Katherine Emma Jones, consiste en un mapeo del Bomb Census de Londres con el fin de hacer accesible al público la información de los lugares de impacto de las bombas, hasta ahora sólo disponible en la sala de consultas del National Archives, a través de dos plataformas digitales interactivas: una página web y una aplicación para dispositivo móvil (Figura 5).

Figura 5. Interfaz gráfica de la página web Bomb Sight. Mapping de WW2 bomb census

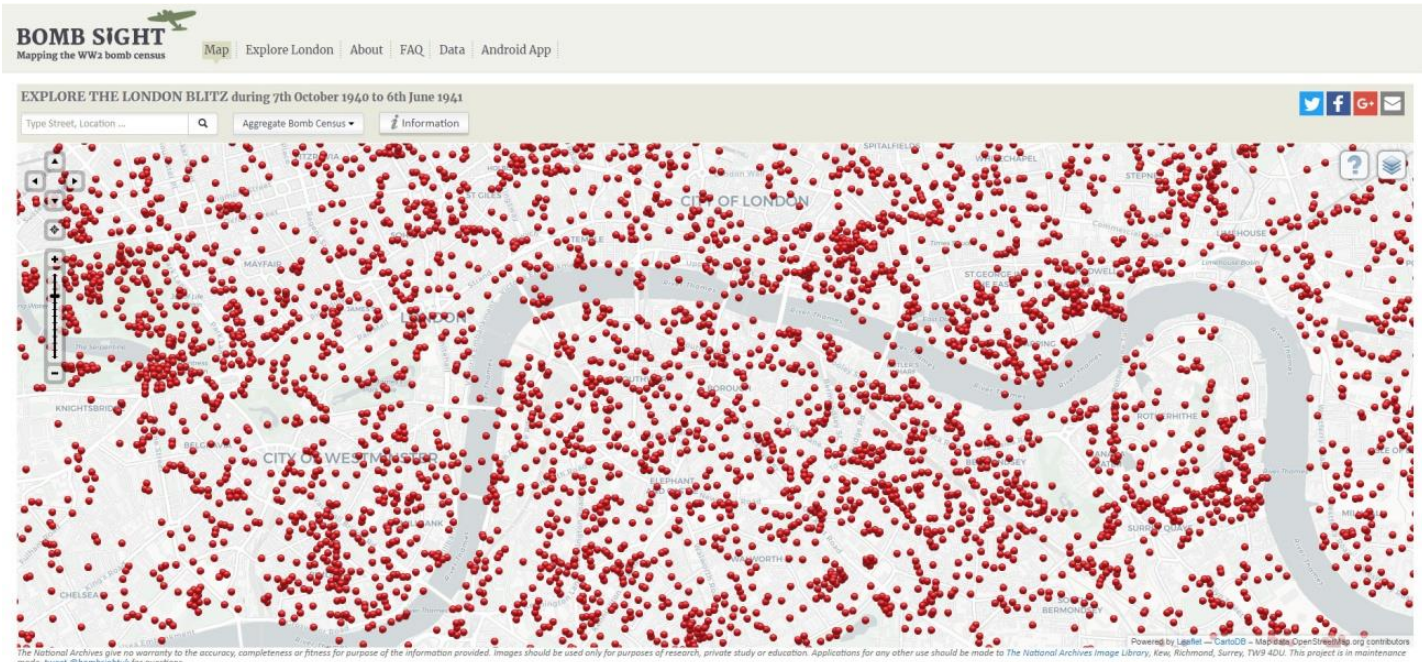

Fuente: recuperado de www.bombsight.org versión 1.0, 2 de marzo de 2018

Dentro de este interés creciente por el conocimiento y difusión de la historia de la destrucción aérea de las ciudades por medios de difusión digital, es preciso citar también el proyecto que dio lugar a la página web Barcelona sota les bombes, que permite un recorrido visual y cronológico de los bombardeos de Barcelona durante la Guerra Civil Española con abundante información fotográfica y datos de las víctimas (Fig. 6).

Figura 6. Interfaz de la página web Barcelona sota les bombes

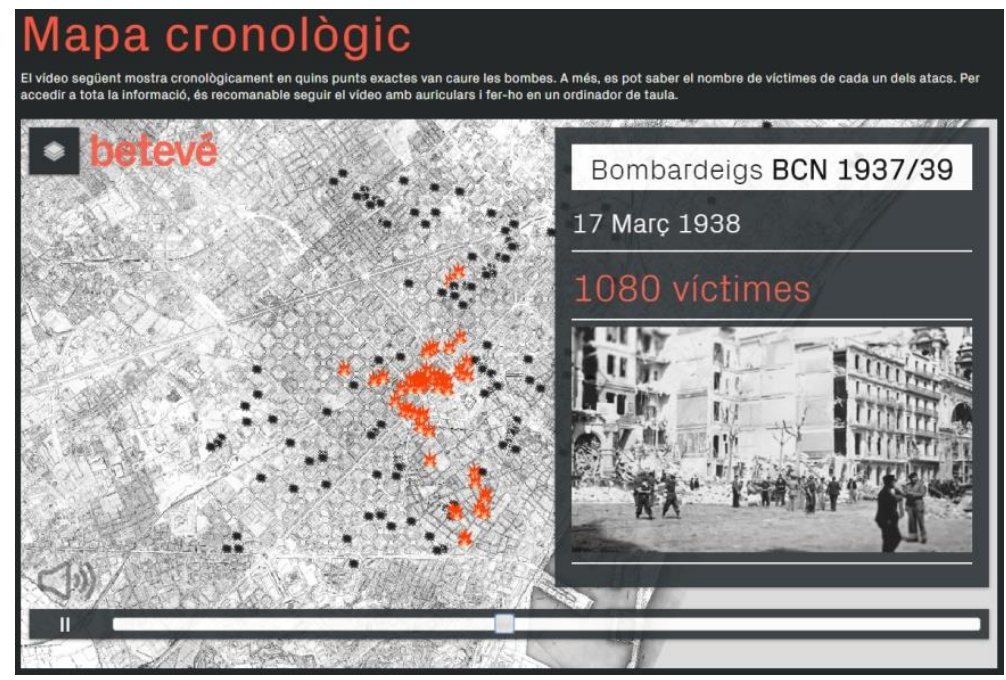

Fuente: recuperado de http://barcelonasotalesbombes.beteve.cat/

${ }^{8}$ bombsight.org

ACE, 15 (43) CC BY-ND 3.0 ES | UPC Barcelona, España | Cartografiar la destrucción. Los bombardeos de la Guerra Civil y el patrimonio inmueble de Madrid. DOI: http://dx.doi.org/10.5821/ace.15.43.9014 
La investigación que planteamos aquí comparte con estos dos últimos proyectos algunos aspectos del método de investigación y el principio de facilitar en el futuro el público acceso al conocimiento de la destrucción sufrida por Madrid durante su guerra más reciente.

\section{Metodología}

\subsection{Las fuentes documentales}

Se han considerado fuentes documentales que refirieran daños en la arquitectura y los espacios urbanos madrileños provocados por los bombardeos entre agosto de 1936 y marzo de 1939. La mayoría de los documentos consultados fueron elaborados durante los meses de la guerra o en los años inmediatamente posteriores. Forma parte de esta fase inicial de la investigación un análisis crítico de las propias fuentes en cuanto a sus características, tipo y cantidad de información que aportan al objeto de estudio y fiabilidad. Entre todas las fuentes empleadas destacan, cuantitativa y cualitativamente los documentos generados por la actividad desarrollada por tres colectivos profesionales que, en esos momentos, representaban la respuesta de la sociedad civil frente a la agresión: los bomberos, que acudían en un primer momento a los edificios atacados para rescatar supervivientes, recuperar cadáveres y apagar fuegos que amenazaban con extenderse; los arquitectos municipales, que organizaban el apuntalamiento y desescombro de los edificios afectados; y los fotorreporteros, que con su trabajo daban testimonio gráfico de algo inédito hasta entonces: la destrucción sistemática de una gran ciudad. La especificidad de estas tres fuentes y el peso de su análisis merece capítulo aparte.

\subsection{Los parámetros para el análisis de la destrucción}

El marco geográfico elegido es el término municipal de Madrid en su extensión durante los años del conflicto. Esto implica que quedan fuera del ámbito de estudio algunos núcleos de población próximos que fueron muy castigados por los bombardeos y que hoy día sí se integran en el término municipal de Madrid, como Tetuán de las Victorias, Vallecas, Puente de Vallecas o Entrevías (Uría, 2010). La información obtenida de las fuentes documentales consultadas se ha ordenado en una base de datos ${ }^{9}$ donde cada registro reúne la información de un edificio afectado, agrupada en tres grandes epígrafes que aglutinan un conjunto de parámetros considerados relevantes para los análisis posteriores:

- Datos del inmueble afectado: referencia catastral, dirección postal actual, dirección postal antigua, identificación de edificios singulares, uso del inmueble durante la guerra y grado de afectación del inmueble.

- Datos del bombardeo: fecha y características del armamento utilizado especificando, al menos, si se trata de un ataque de aviación con bombas explosivas, con bombas incendiarias o un ataque de artillería.

- Datos de las fuentes empleadas: tipo de fuente y referencias documentales o bibliográficas.

\subsection{Ubicar la información}

La tercera fase de trabajo ha consistido en la georreferenciación de la base de datos elaborada10. Este proceso se ha llevado a cabo sobre la base cartográfica vectorial del plano catastral de Madrid ${ }^{11}$,

\footnotetext{
${ }^{9}$ Para la elaboración de la base de datos se ha empleado el software de código abierto Apache OpenOffice 4, desarrollado por The Apache Software Foundation: http://www.openoffice.org/welcome/credits.html.

10 Para el trabajo con Sistemas de Información Geográfica (GIS) se ha empleado el software de código abierto QGIS, que se distribuye bajo la Licencia Pública General GNU.

${ }^{11}$ Dirección General del Catastro. Ministerio de Economía y Hacienda.
}

ACE, 15 (43) CC BY-ND 3.0 ES | UPC Barcelona, España | Cartografiar la destrucción. Los bombardeos de la Guerra Civil

y el patrimonio inmueble de Madrid. DOI: http://dx.doi.org/10.5821/ace.15.43.9014 
identificando cada edificio afectado con la referencia de la finca catastral actual que ocupa el mismo lugar. A pesar de tratarse de un tejido urbano en su mayor parte consolidado, existe una dificultad inherente a este procedimiento de trabajo, debida a las modificaciones producidas en los últimos ochenta años en la denominación, naturaleza o extensión de las fincas, por agregación o segregación, o por alteración del trazado de calles o plazas. Las fuentes documentales consultadas se refieren, cuando especifican direcciones postales, a vías públicas que, en algunos casos, han cambiado su nombre o su numeración. Ha sido preciso, por tanto, una labor de identificación de la dirección postal actual de numerosos edificios, lo cual se ha llevado a cabo consultando el callejero histórico del Ayuntamiento de Madrid ${ }^{12}$, el plano catastral elaborado por los técnicos del CRRSM ${ }^{13}$ y el plano parcelario de la década de los años cuarenta, cuyos pliegos son conocidos como Catastrones ${ }^{14}$.

\subsection{El análisis de la destrucción}

El trabajo mediante software GIS ha permitido ubicar y procesar la información, ordenándola y visualizándola en función de diferentes parámetros para su posterior análisis. Se propone analizar tres parámetros fundamentales que permiten profundizar en el conocimiento del objeto investigado: la cronología de los bombardeos (cuándo); la localización de los edificios afectados y la identificación de posibles patrones de distribución (dónde); y el tipo de armamento utilizado y grado de destrucción del patrimonio inmueble (cómo). También se propone buscar posibles relaciones entre estos parámetros de modo que, a partir de los datos de los que existe constancia documental, se puedan plantear hipótesis razonables sobre otros de los que no existe.

\subsection{La narración gráfica}

La última fase del proceso ha consistido en el planteamiento de unos criterios gráficos adecuados que faciliten una lectura de los análisis realizados y permitan una mejor comprensión del alcance de la destrucción provocada en la ciudad. Básicamente se ha traducido a diferentes capas de dibujo tres tipos de elementos: el soporte físico urbano, los inmuebles afectados y los impactos de proyectiles. La representación del soporte físico atiende a una doble realidad. Por un lado, el Madrid de 1936, una ciudad diferente en la configuración de determinados ámbitos puntuales. Es el caso, por ejemplo, de las plazas de España o de la Moncloa, del espacio que ocupaba el Cuartel de la Montaña, del tejido urbano entorno a la actual Gran Vía de San Francisco o de las zonas próximas a las márgenes del Manzanares. En los casos en los que la transformación de las antiguas fincas es tal que no permite la identificación con las actuales, se ha llevado a cabo una reconstitución gráfica de su estado durante la guerra, tomando como referencias, de nuevo, el parcelario del CRRSM y los Catastrones. Además, el Madrid de 1936 es una ciudad fundamentalmente diferente en su tamaño. Visualizar sus límites es importante para comprender la extensión de los bombardeos.

Por otro lado, atiende al estado actual de la ciudad, de forma que el lector encuentre elementos de referencia que le permitan identificar la ciudad que conoce o en la que vive. Esta superposición de estados, análogamente a la superposición de imágenes fotográficas de Docherty, Marquerie y Maharg, permite relacionar visualmente la ciudad actual con su historia.

Si de visualizar la destrucción de la ciudad se trata, más que en otro tipo de realidades urbanas, parece imprescindible representar la causa de dicha destrucción, es decir el impacto de los proyectiles. La ubicación de los impactos se ha podido deducir, con mayor o menor precisión, a partir

\footnotetext{
12 Accesible en Aplicaciones Base de Datos Ciudad: http://www-2.munimadrid.es/ConsultasBDCWebSqllnternet/jsp/index.jsp

13 El plano parcelario de Madrid más reciente en 1936 era el plano "Información sobre la ciudad", de 1929. El fragmento de plano contenido en la Memoria del CRRSM abarca, reducidas, las hojas 65, 66, 75 y 76 del parcelario de 1929. Además, contiene información ausente en este último, como los linderos entre fincas de una misma manzana o las trazas de las plantas de algunos edificios singulares, como el palacio de Liria, la iglesia del Buen Suceso, el Cuartel de la Montaña, el Teatro Real, el Palacio Real y el Ayuntamiento.

${ }^{14}$ Archivo Cartográfico del Ayuntamiento de Madrid, accesible desde el geoportal del Ayuntamiento de Madrid: https://geoportal.madrid.es/ 
de la información aportada por los documentos gráficos disponibles en algunos casos: fotografías y planos. En la mayor parte de los casos, sin embargo, no es posible y se ha optado por un criterio general de ubicar un impacto en el área ocupada por los edificios afectados, pudiendo considerarse esta aproximación suficientemente precisa a escala urbana.

\section{Tres profesiones para documentar la destrucción: bomberos, arquitectos y fotorreporteros}

\subsection{El cuerpo de bomberos de Madrid}

Los libros de intervención del Archivo Histórico del Cuerpo de Bomberos de Madrid constituyen una fuente de inestimable valor para conocer la intensidad y extensión del urbicidio madrileño. En estos libros se registraba cada salida que efectuaba una dotación de bomberos para atender cualquier siniestro, indicando fecha, hora, dirección, motivo de la intervención y, en ocasiones, observaciones específicas (Figura 7). Así, además de documentar la dirección de 759 edificios en los que se intervino a causa de los diversos bombardeos, aportan una información muy detallada que no se ha podido encontrar en otras fuentes, incluidos los archivos militares. Por un lado, la fecha, hora y dirección de las intervenciones permiten reconstruir la cronología y las zonas de la ciudad donde se desarrollaron los ataques. Por otro, la causa de la intervención indica, en muchos casos de forma inequívoca, el tipo de ataque, lo que, como se verá, permite deducir indirectamente la intensidad de los daños producidos. En efecto, en muchos de los registros se diferencia con las expresiones "obús" y "bombardeo de aviación" si los proyectiles fueron lanzados por la artillería o si fueron arrojados desde aeronaves. En otros registros, el escueto término "bombardeo", no indica con certeza el tipo de ataque. En estos casos este dato ha tenido que ser deducido considerando otras fuentes. La fecha, por ejemplo, suele ser un dato determinante ya que, gracias a las fuentes militares, podemos descartar uno u otro tipo de ataque. El término "reproducción", que aparece con cierta frecuencia, suele indicar un ataque con bombas incendiarias, ya que los fuegos que provocaban en las tradicionales armaduras de madera de los tejados madrileños se reavivaban, en ocasiones, en los días siguientes al ataque.

Es preciso considerar también las limitaciones de estos registros, que no son en absoluto exhaustivos. En primer lugar, los medios materiales y personales del cuerpo de bomberos fueron claramente insuficientes para atender a todos los siniestros que se produjeron en determinados momentos por la intensidad de los bombardeos: "Los bomberos se veían impotentes para combatir tantos incendios importantes y simultáneos. En muchos edificios se renunciaba a echar agua y sólo quedaba esperar a que se quemasen, y rescatar a las personas" (De Vicente, 2014a, pág. 101). Los libros de intervención corroboran esta circunstancia con la indicación "sin precisar pues actuó todo el Servicio", manuscrita en muchas de las páginas correspondientes al mes de noviembre de 1936. En segundo lugar, hay zonas de la ciudad que apenas pudieron ser atendidas por los bomberos a pesar de que fueron muy afectadas por los ataques. Se trata fundamentalmente de las llamadas zonas batidas, como el barrio de Argüelles, la cornisa del Manzanares, las áreas próximas al río y las barriadas al sur del Manzanares: paseo de Extremadura, puente de Toledo y Usera. Eran zonas extremadamente peligrosas por su proximidad al frente donde la población había sido evacuada casi en su totalidad, por lo que la labor de los bomberos no era tan necesaria.

Finalmente, hay que señalar cierto grado de imprecisión en las direcciones de los inmuebles apuntadas en los libros de intervención las cuales cabe pensar que se refieren, en su mayor parte, a los edificios afectados, aunque hay casos en los que cabe plantearse que se refieran a edificios adyacentes o, incluso, a un conjunto de varios edificios próximos entre sí.

ACE, 15 (43) CC BY-ND 3.0 ES | UPC Barcelona, España | Cartografiar la destrucción. Los bombardeos de la Guerra Civil y el patrimonio inmueble de Madrid. DOI: http://dx.doi.org/10.5821/ace.15.43.9014 


\section{ACE Architecture, City and Environment}

Figura 7. Libro de intervenciones del cuerpo de bomberos de Madrid

\begin{tabular}{|c|c|c|c|c|c|c|}
\hline \multirow{2}{*}{$\begin{array}{l}\text { Xemero } \\
\text { ne } \\
\text { OKDEN }\end{array}$} & \multicolumn{3}{|c|}{ FECHA DEL. SINIESTRO } & \multirow{2}{*}{ 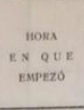 } & \multirow{2}{*}{ SITIO EN QUE HA OCURRIDO } & \multirow{2}{*}{ SUS CAUSAS } \\
\hline & $\triangle 80$ & ses & oth & & & \\
\hline 1487 & $\infty$ & oriembre & 9 & $\begin{array}{l}d e \\
1 \int^{\prime} 10\end{array}$ & illa & hombardeo \\
\hline 1488 & & • & i & a laf & & de aniauion \\
\hline 1489 & & : & · & $19^{\prime}-$ & Larqueis del lomillas & , \\
\hline $\begin{array}{l}1490 \\
1491\end{array}$ & & , & $\dot{.}$ & & $\begin{array}{l}\text { Forge Juan } 39 \\
\text { Eotacion del porte }\end{array}$ & $"$ \\
\hline 1492 & & . & ". & & $\begin{array}{l}\text { Etacida del Norte } \\
\text { Qovida de Segovia }\end{array}$ & . \\
\hline 1493 & & - & . & & degeciras degar & . \\
\hline 1494 & & . & . & & \$: de les pontones & " \\
\hline 1495 & & - & . & & Gide Looler &.$"$ \\
\hline 1496 & & - & . & & Sacramento & , \\
\hline 1497 & & - & , & & CVelarques 30 & . \\
\hline 1498 & & $"$ & 4 & & Som Bermardo 2 & , \\
\hline 1499 & & " & . & & Casa de elorques (e.u) & $"$ \\
\hline 1500 & & * & 4 & & Cava Baya 10 & , \\
\hline 1501 & & " & 4 & & uto esq / Bola & $"$ \\
\hline 1502 & & " & . & & Salacio Vaitonal & , \\
\hline 1503 & & 4 & " & & Sanco de Espaina & , \\
\hline
\end{tabular}

Imagen de la página correspondiente al día 9 de noviembre de 1936 entre las 15:10 y las 19:00 horas. Fuente: Archivo Histórico del Cuerpo de Bomberos de Madrid.

\subsection{Los arquitectos municipales}

Durante los primeros meses de bombardeos las diferentes administraciones que operaban en la ciudad, entre ellas el Ayuntamiento, con su cuerpo técnico de arquitectos, respondieron por separado para paliar los efectos de los ataques. En abril de 1937 se constituyó el Comité de Reforma, Reconstrucción y Saneamiento de Madrid (CRSSM) con el fin de coordinar los trabajos de protección, auxilio, desescombro y reconstrucción. Con una actitud metódica los arquitectos y aparejadores de la Sección de Socorro de fincas bombardeadas y de la Oficina de Estudios Técnicos del Comité llevaron a cabo una catalogación, clasificación y levantamiento parciales del estado de los inmuebles de la ciudad (Bustamante, 1996). La documentación gráfica completa elaborada por el CRRSM permanece sin localizar a día de hoy, pero conocemos una parte gracias a la memoria publicada en mayo de 1938. En la selección de planos y dibujos extractados para esta memoria se puede apreciar el rigor y el empeño de los técnicos en documentar los daños en edificios con el fin de solucionar, de la forma más sistemática, uno de los grandes problemas de la ciudad asediada y afrontar, con el conocimiento necesario, la posterior reconstrucción (Figura 8).

Según la Memoria del primer año de funcionamiento del CRRSM, la Oficina de Estudios Técnicos trabajó con reproducciones de las hojas del plano parcelario de Madrid a escala 1/2.000, representando con diferentes tonos de color el grado de deterioro en cada finca (CRRSM, 1938). La información era facilitada por la sección de Socorro de fincas bombardeadas que, dividida en doce equipos de distrito, acudían a los siniestros. Esta documentación gráfica constituye un antecedente inmediato del Bomb Census y de los Bomb Damage Maps londinenses y de ella sólo se conserva un detalle correspondiente al barrio de Argüelles (Figura 9). La Memoria del CRRSM muestra también dibujos y croquis de inmuebles afectados, así como perspectivas axonométricas de algunas zonas, donde se describe el estado de los edificios tras los ataques. 


\section{ACE Architecture, City and Environment}

Figura 8. Croquis de apeo realizado por los técnicos del Servicio de Socorro de Bombardeos
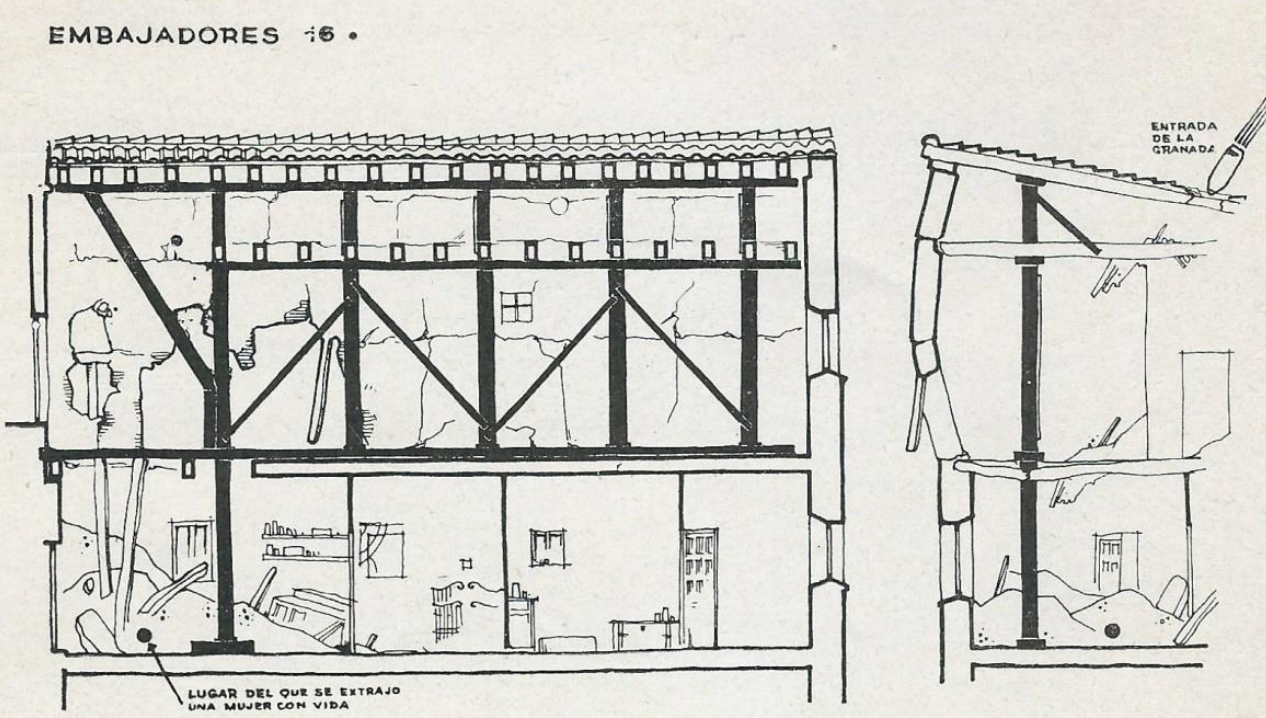

Fuente: Memoria. Madrid 1937-1938 (CRRSM, 1938, 10).

Figura 9. Detalle del parcelario elaborado por los técnicos del CRRSM con el estado de las fincas

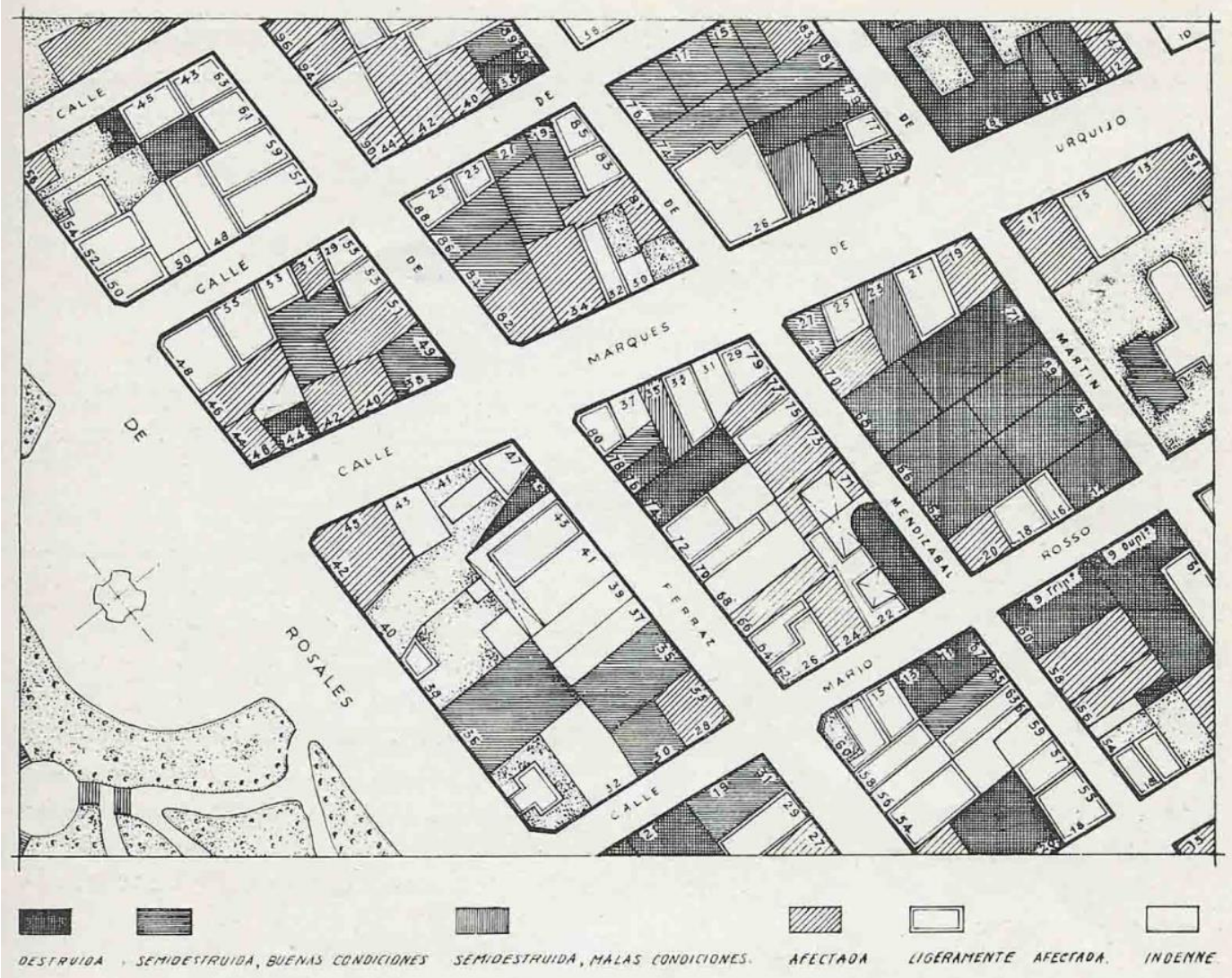

Fuente: Memoria. Madrid 1937-1938 (CRRSM, 1938, 9).

ACE, 15 (43) CC BY-ND 3.0 ES | UPC Barcelona, España | Cartografiar la destrucción. Los bombardeos de la Guerra Civil 
Además, contamos con una serie de planos parciales, fotografiados por José Lino Vaamonde ${ }^{15}$, tres de los cuales se publicaron en la revista 5o Regimiento. Estos planos reflejan, en los entornos de la Real Academia de Bellas Artes, del Paseo del Prado y en el Distrito de Congreso, los impactos de los proyectiles que se produjeron entre el 10 y el 30 de noviembre de 1936, distinguiendo entre bombas explosivas, bombas incendiarias y granadas de artillería. Finalmente, se conservan dos planos de los edificios de la Biblioteca Nacional y Museo Arqueológico y del Museo del Prado, donde se indican los impactos de las bombas incendiarias arrojadas el 16 de noviembre (Figura 10).

Figura 10. Museo del Prado y sus alrededores, con los impactos del bombardeo del 16 de noviembre de 1936

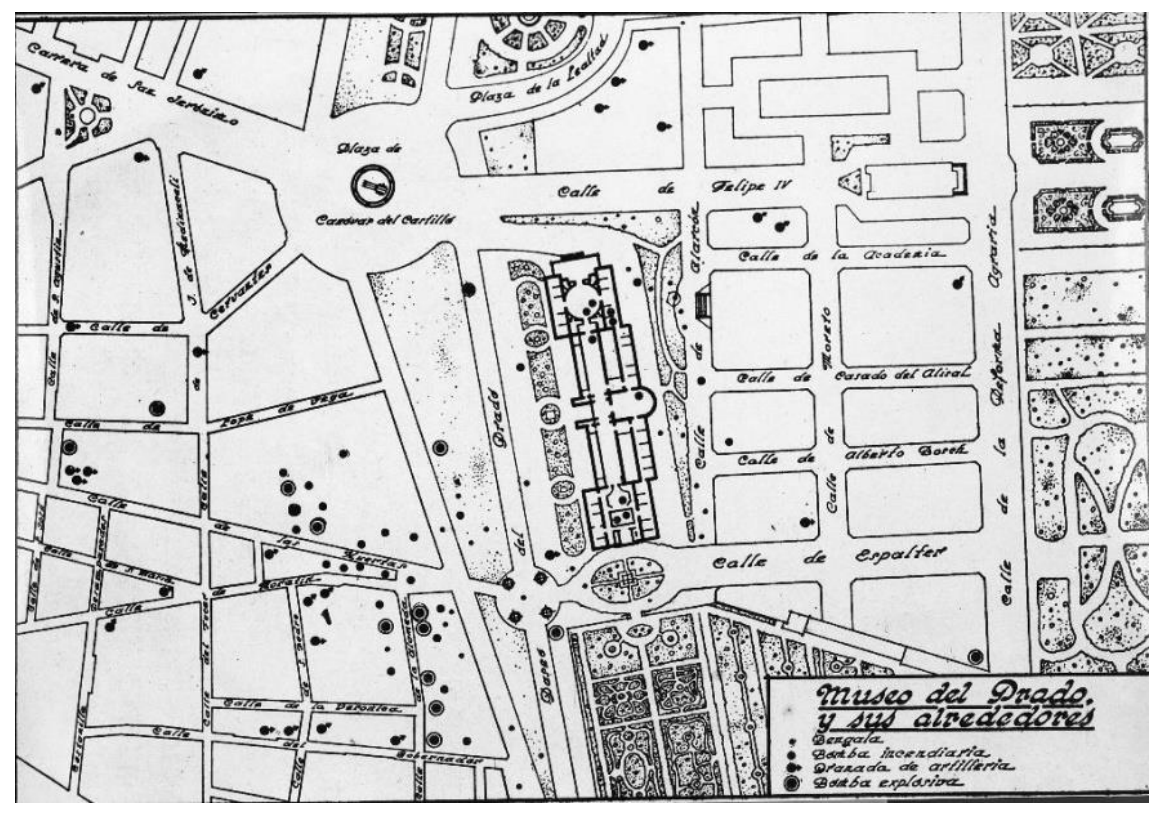

Fuente: Archivo Vaamonde. Instituto del Patrimonio Cultural de España.

\subsection{Los fotorreporteros}

La guerra tuvo gran repercusión internacional, lo que se refleja en la cantidad de fotorreporteros que cubrieron el conflicto y, particularmente, sus repercusiones en Madrid, cuya caída en manos del ejército sublevado se daba por hecha en noviembre de 1936. La Guerra Civil Española fue "el primer conflicto bélico seguido, día a día, tanto por fotógrafos españoles como por aquellos llegados de todo el mundo" (De las Heras, 2015, pág. 8). Gran cantidad de imágenes conservadas informan de la destrucción de Madrid, bien como protagonista o como escenario donde los protagonistas son, generalmente, los habitantes.

Para llevar a cabo esta investigación se han consultado más de 500 imágenes fotográficas procedentes principalmente de las colecciones de la Biblioteca Nacional de España y del Archivo Fotográfico de la Delegación de Propaganda de Madrid, conocido como Archivo Rojo (Archivo General de la Administración). No obstante, se han consultado también otros fondos y archivos, entre los que podemos destacar el Archivo Histórico del Partido Comunista de España (Biblioteca Histórica de la Universidad Complutense de Madrid); el Archivo Vaamonde (Instituto del Patrimonio Cultural de España); la fototeca de la agencia EFE; la colección de la agencia ASF; y la colección Juan Miguel Pando Barrero (Museo Nacional Centro de Arte Reina Sofía).

\footnotetext{
${ }^{15}$ Archivo Vaamonde. Instituto del Patrimonio Cultural de España.
} 


\section{ACE Architecture, City and Environment}

La mayor parte de las fotografías carece de una descripción precisa de la ubicación de las imágenes o la descripción es errónea. Ha sido preciso llevar a cabo un proceso de identificación de los edificios fotografiados a partir de las referencias visuales que contienen las imágenes. Estas referencias han permitido identificar la mayor parte de los edificios fotografiados, aunque ya no existan o su aspecto se haya visto alterado. A pesar de ello, un pequeño porcentaje de fotografías carece de las referencias necesarias para poder llevar a cabo esta identificación.

Después de este proceso ha sido posible localizar más de 700 edificios bombardeados, aunque sólo una pequeña parte de los edificios dañados en Madrid fueron fotografiados ${ }^{16}$. Estos documentos gráficos aportan información muy interesante sobre el grado de destrucción de los inmuebles y el efecto provocado por los diferentes tipos de proyectiles empleados (Figura 11).

Figura 11. Documentos fotográficos de los efectos de los bombardeos en Madrid.

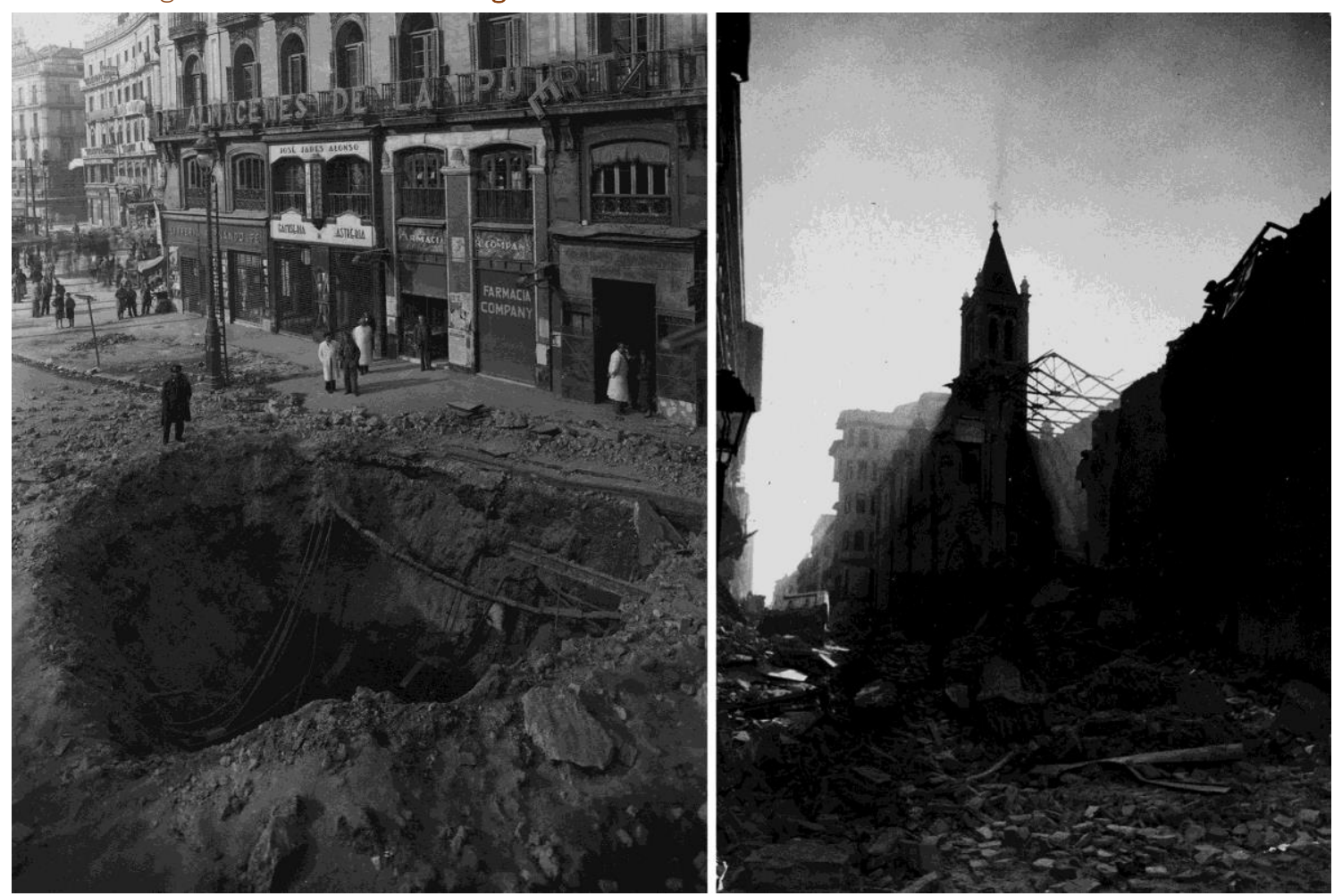

Izquierda: Desembocadura de la calle de Alcalá en la Puerta del Sol. Derecha: calle de Juan Álvarez Mendizábal, a la altura del no65. Fuente: Biblioteca Nacional de España.

Aunque por su origen y motivación sean totalmente diferentes, son también relevantes algunas fotografías aéreas correspondientes a vuelos de reconocimiento de la aviación sublevada durante la contienda ${ }^{17}$, así como las imágenes del vuelo fotogramétrico realizado por la aviación estadounidense en 1941. Las primeras permiten apreciar los efectos de los bombardeos en la zona de Argüelles y

\footnotetext{
${ }^{16}$ El CRRSM maneja cifras mucho más elevadas que los casi 2.000 edificios documentados en este estudio. Por un lado, el Servicio de Socorro a Bombardeos informa de 6.036 siniestros atendidos en el año 1937 (CRRSM, 1938). Por otro, la Sección de Estadística de la Oficina de Estudios Técnicos informa de 3.543 edificios deteriorados en diverso grado, desde destruidos a ligeramente afectados, de las 7.922 casas inspeccionadas (CRRSM, 1938). Es preciso señalar que sólo se pudieron inspeccionar completamente los distritos de Centro, Hospicio y Palacio.

No obstante, parece razonable suponer que la documentación consultada refiere el grueso de los edificios que sufrieron un mayor grado de destrucción y atribuir la falta de documentación de muchos de los edificios afectados a la escasa gravedad de los daños que sufrieron. 17 Archivo Histórico del Ejército del Aire y Archivo General Militar de Ávila.
} 


\section{ACE Architecture, City and Environment}

Ciudad Universitaria. Los fotogramas del vuelo de 1941, en cambio, cubren la mayor parte del casco urbano de entonces ${ }^{18}$. Estas imágenes no permiten identificar daños de poca extensión en los edificios, como los provocados por obuses o granadas de artillería, fundamentalmente porque la mayor parte de ellos habían sido ya reparados para facilitar la habitabilidad de numerosas viviendas. No obstante, han permitido confirmar la destrucción de muchos edificios documentada en otras fuentes e identificar muchos otros que se ubicaban en zonas a las que apenas habían accedido bomberos, arquitectos municipales o fotógrafos, por estar muy próximas al frente y ser de peligroso acceso, como la cornisa del Manzanares o el actual distrito de Arganzuela. Cabe señalar como dato relevante la identificación de numerosas cubiertas de edificios que ardieron total o parcialmente por efecto de las bombas incendiarias (Fig. 12).

Figura 12. Detalle de fotograma del vuelo de 1941.

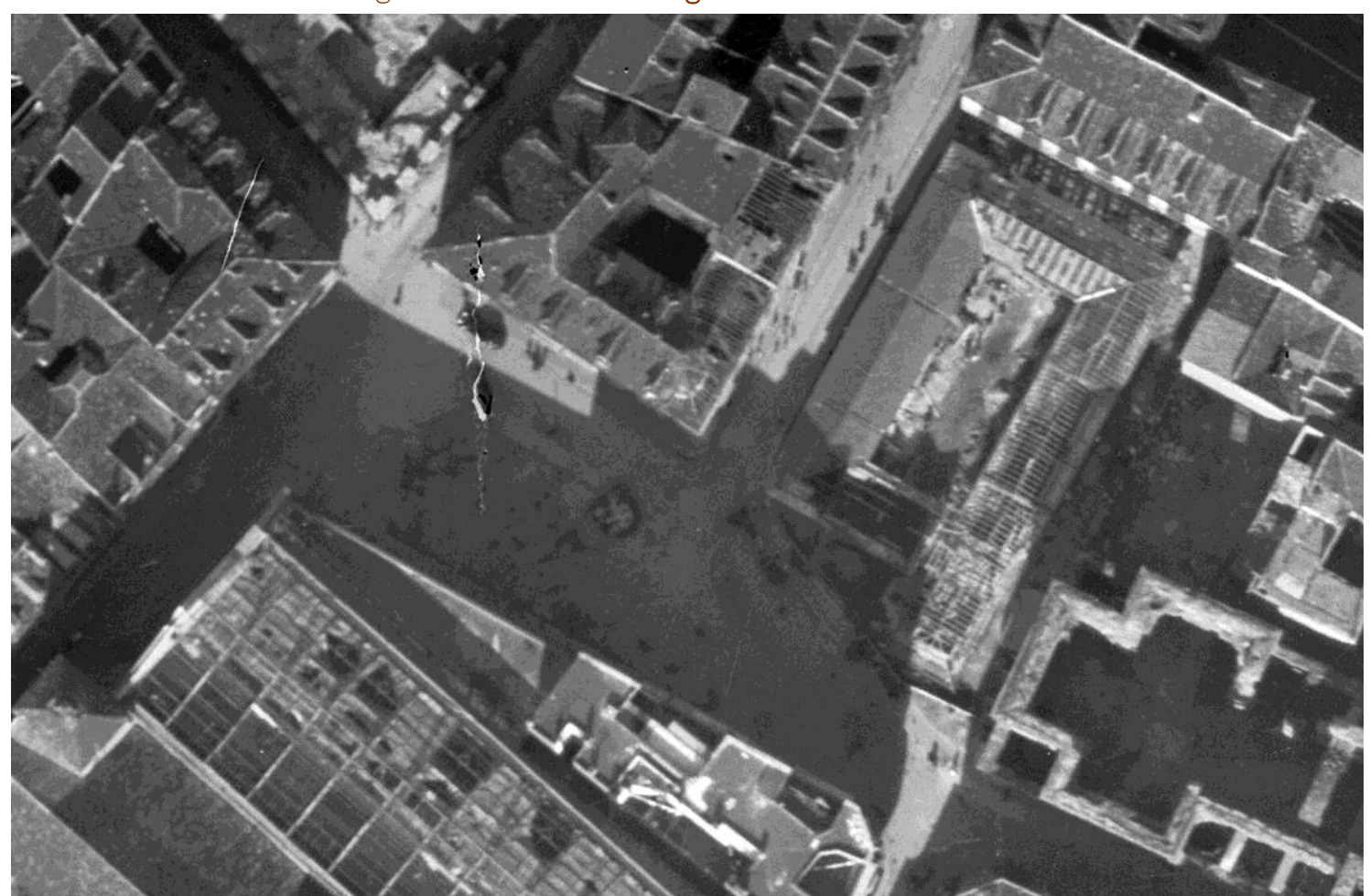

Se aprecian numerosos edificios en el entorno de la plaza del Carmen con las cubiertas afectadas por las bombas incendiarias arrojadas en el bombardeo del 17 de noviembre de 1936. A la derecha de la imagen también se aprecian los restos de la iglesia de San Luis cuyo incendio se provocó, sin embargo, durante los disturbios del 13 de marzo de 1936. Fuente: Archivo Cartográfico del Ayuntamiento de Madrid.

Extraña, sin embargo, la ausencia de fotografías aéreas tomadas por los aviones atacantes durante las operaciones diurnas, al modo en que fueron tomadas las que conservamos de los bombardeos de Guernica, Barcelona y muchas otras poblaciones de Levante. Con seguridad debieron de tomarse también en los ataques a Madrid, dado el carácter experimental, desde el punto de vista del armamento y de la táctica militar, que dieron las aviaciones alemana e italiana a los bombardeos de poblaciones durante la contienda española.

\footnotetext{
18 Los límites aproximados del ámbito fotografiado en el vuelo de 1941 son la calle de Fernando el Católico y el Paseo del General Martínez Campos por el norte; la calle de Serrano y Alfonso XII por el este; y el río Manzanares por el sur y el oeste.
} 


\subsection{Otras fuentes}

Prensa histórica. A pesar de la repercusión mediática del conflicto y de la gran cantidad de fotografías que se produjeron, después de consultar diversas publicaciones en hemerotecas digitales (diarios ABC, Crónica, La Libertad, La Voz, diario gráfico Ahora y semanario Mundo Gráfico) ${ }^{19}$, se ha comprobado que la prensa escrita aporta relativamente pocos datos concretos sobre los efectos de los bombardeos sobre la población. El control de la censura por parte de la Delegación de Propaganda de Madrid, preocupada por evitar que cundiera la desmoralización entre los habitantes y por no facilitar información útil al enemigo sobre posibles objetivos militares, impedía la publicación de crónicas detalladas sobre los bombardeos: "Paradoxically, during the Battle of Madrid images of the bombed city were mainly kept out of Spanish Republican newspapers at a time when they featured prominently in the foreign press. The intention was certainly to keep defeatism at bay"20 (Minchom, 2015, pág. 99). Algunas de las crónicas más descriptivas fueron precisamente las del corresponsal francés Luis Delaprée, que fueron suavizadas, antes de ser publicadas, por los redactores del periódico Paris-Soir. En la prensa española sólo trascendieron datos de daños provocados en algunos edificios que tuvieron especial repercusión internacional, como los bombardeos del palacio de Liria, del Museo del Prado, o de la Biblioteca Nacional. La prensa gráfica publicó sólo algunas imágenes de edificios no representativos destruidos, pero, en cualquier caso, muy pocas en comparación con los daños realmente sufridos.

Como excepción, una de las publicaciones que más información ha aportado a la investigación es "Bombardeos fascistas", número 8 de la serie Documentos históricos de Ediciones 5o Regimiento ${ }^{21}$. En este monográfico sobre los bombardeos aéreos y artilleros sobre Madrid se publica, entre otras informaciones relevantes, un listado de 402 inmuebles afectados, identificados por su dirección postal22, agrupados por distritos y aclarando que los datos se refieren específicamente a los bombardeos de los días 10 al 19 de noviembre y 6 al 12 de diciembre de 1936. También se publicaron en este número tres planos a pequeña escala con la localización de impactos de bombas en los edificios del barrio de las Letras entre los días 10 y 30 de noviembre de 1936, elaborados por el arquitecto encargado del socorro en la zona. Cada plano hace referencia a un tipo de proyectil, distinguiendo entre obuses, lanzados por la artillería, y bombas de aviación, tanto incendiarias como explosivas. Finalmente se publicaron en este número especial numerosas fotografías, algunas de las cuales se encuentran también en otros archivos.

Fuentes bibliográficas y literarias. Se han considerado las descripciones de los bombardeos y de sus efectos en monografías historiográficas como las de Montoliú (2000), Solé y Villaroya (2003), De Vicente (2014a y 2014b), Minchom (2015) o Andrés (2017). También se han considerado los datos encontrados en relatos, diarios y memorias escritos por testigos presenciales de los acontecimientos. Muchos de ellos eran habitantes de Madrid, pero otros eran extranjeros, generalmente corresponsales de prensa, que vinieron a cubrir informativamente los sucesos de la guerra. Entre los numerosos testimonios existentes cabe destacar los de Délano (1937), Cuarental (1992), Chueca (1996) y Koltsov (2009). Además de estos, es preciso señalar las obras de escritores de primera línea como La Llama ${ }^{23}$, de Arturo Barea; Telefónica, de Ilsa Barea-Kulcsar; Memoria de la melancolía, de María Teresa León;

\footnotetext{
${ }^{19}$ El diario $A B C$ se ha consultado a través de la hemeroteca digital ABC. El diario gráfico Ahora se ha consultado en la Hemeroteca Municipal a través del portal Memoria de Madrid. El resto de periódicos se han consultado en la Hemeroteca Digital de la Biblioteca Nacional de España.

20 "Paradójicamente, durante la Batalla de Madrid, las imágenes de la ciudad bombardeada se mantuvieron principalmente fuera de los periódicos republicanos españoles en un momento en que aparecían de forma destacada en la prensa extranjera. La intención era, ciertamente, mantener a raya el derrotismo" (traducción de los autores).

21 Archivo Histórico Nacional (FC-CAUSA_GENERAL, 1581, Exp. 20).

22 Sólo en el caso de algunos inmuebles singulares están identificados por el nombre popular con que se conocían, como el Teatro Cómico.

23 Tercer volumen de la trilogía La forja de un rebelde.
} 
- Confieso que he vivido, de Pablo Neruda, entre otras. Especialmente interesantes son las descripciones de su relación personal con la arquitectura y la ciudad que habitaron (Fogo, 2012). Naturalmente, el valor como testimonios de los bombardeos de estas obras literarias trascienden con mucho el mero dato, y enriquecen la comprensión de esta trágica realidad. No obstante, este innegable interés, de cara a la elaboración de la cartografía de los bombardeos como primer objetivo de esta investigación, sólo hemos considerado la información que pudiera ser localizada sobre una base cartográfica.

Documentos militares. Se han podido obtener algunos datos sobre edificios afectados por los bombardeos a partir de las Órdenes de Operación aéreas de la Jefatura del Aire Nacional en Madrid, de los Partes de Operación aérea de la aviación sublevada, de los Partes de Guerra Republicanos y de los boletines diarios de Información del Estado Mayor (De Vicente, 2014b). No obstante, las órdenes de operación sólo especifican objetivos y los partes no suelen informar de edificios concretos afectados más que en casos singulares.

Cartografía municipal. Son especialmente interesantes como fuente de datos los Catastrones, nombre por el que se conoce a los pliegos del plano parcelario de Madrid dibujado en color, a escala 1/500, durante los primeros años de la década de $1940^{24}$. Estos planos reflejan el estado de la ciudad en la inmediata posguerra, cuando apenas había comenzado la reconstrucción de la mayor parte de los edificios que resultaron irrecuperables a consecuencia de los bombardeos, y figuran con los códigos correspondientes a "solar" (en blanco) o "en ruinas" (en blanco y con contorno rojo a trazos). No obstante, para constatar que las fincas solares se encontraban edificadas ya antes de los bombardeos, se han procedido a contrastar los Catastrones con los fotogramas del vuelo de 1929 (Figura 13).

Figura 13. Estado del entorno de la plaza de la Moncloa antes y después de la guerra
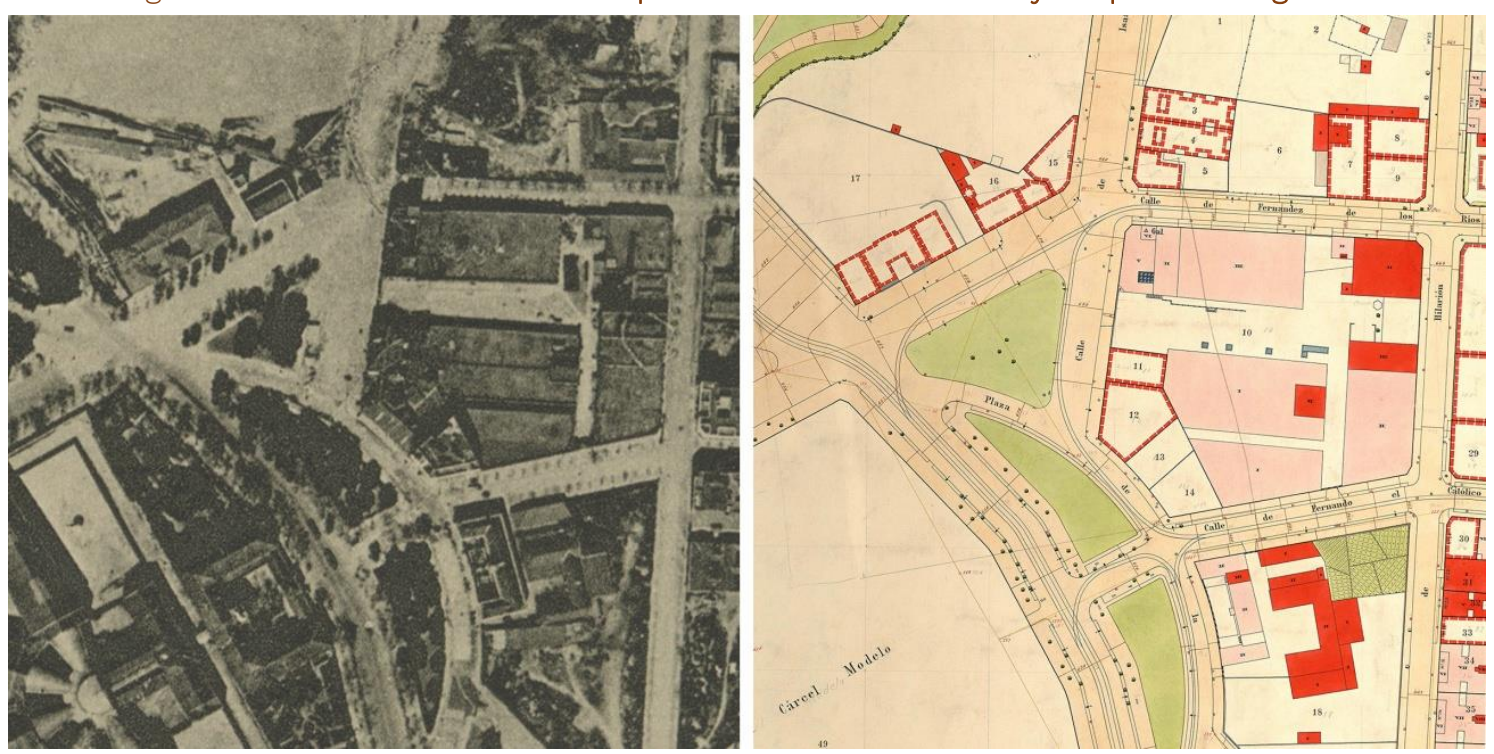

Izquierda: detalle de fotograma del vuelo de 1929. Derecha: detalle del pliego 55-III del plano parcelario de Madrid de los años posteriores a la guerra. Las parcelas en blanco son solares, muchos de los cuales estaban edificados antes de la guerra. El código de línea roja a trazos indica solares con edificios en ruinas. Fuente: Archivo Cartográfico del Ayuntamiento de Madrid.

\footnotetext{
${ }^{24}$ Archivo Cartográfico del Ayuntamiento de Madrid.
} 


\subsection{Análisis de las fuentes}

Del análisis de las características de las diferentes fuentes documentales empleadas se ha podido constatar un elevado grado de heterogeneidad, tanto en la cantidad como en el tipo de información que aportan. Los registros de los libros de intervención del cuerpo de bomberos informan sobre el cuándo y el dónde y, en ocasiones, especifican el tipo de bombardeo. Apenas hacen referencia sin embargo a los daños producidos. En cambio, las imágenes fotográficas evidencian este aspecto y suelen contener suficientes referencias como para deducir el lugar, pero no informan sobre cuándo sucedió el ataque. Los dibujos de los arquitectos municipales suelen ser descriptivos en cuanto al grado de afectación de los edificios, pero no informan de la fecha del bombardeo. Finalmente, las listas de edificios bombardeados publicadas, apenas aportan más que el lugar del siniestro. De todo ello se puede deducir que todas las fuentes conservadas son incompletas. Primero, porque no refieren todos los edificios afectados por los bombardeos ${ }^{25}$. Pero también porque ninguna aporta todos los datos que, de cada siniestro, sería pertinente conocer.

Por otro lado, la fiabilidad de las fuentes primarias consultadas se considera fuera de toda duda razonable por diversos motivos. Dejando a un lado los documentos fotográficos, cuya veracidad es incuestionable, tanto los libros de intervención de los bomberos como el trabajo desarrollado por los arquitectos al servicio del socorro a bombardeos son producto de una actividad profesional orientada a la protección civil cuya eficacia depende, en buena medida, de la fiabilidad de la información elaborada. Además, el hecho de que casi un tercio de los edificios (28\%) están documentados en más de una fuente, lejos de poner en duda la veracidad del resto de los siniestros registrados, redunda en la mayor fiabilidad de todas las fuentes y datos registrados, con las limitaciones que de ellas ya se han descrito en los puntos anteriores.

Sólo de la publicación "Bombardeos fascistas" podría cuestionarse su validez en el sentido de que la información publicada pudiera verse afectada por intereses de carácter político o propagandístico. Esta sospecha, sin embargo, pierde consistencia teniendo en cuenta que el origen declarado de la información son los equipos de socorro de Arquitectura y que, en este caso, más de la mitad (56\%) de los edificios registrados en los "Datos sobre los bombardeos de las viviendas" se encuentran también documentados en otras fuentes.

\section{Visualización y análisis: completando el mosaico de los bombardeos}

Hasta la fecha se han podido documentar más de 1.900 edificios y espacios públicos dañados, en mayor o menor medida, por efecto de las bombas. A partir de la ordenación de la información en una base de datos y de su geolocalización sobre la base del plano catastral de Madrid, se ha procedido a cartografiar los diversos parámetros que permiten una mayor aproximación a la comprensión de la destrucción de la ciudad durante la guerra. El análisis de los patrones que revelan los datos obtenidos en primera instancia, permite comprobar, como veremos, que los parámetros estudiados están íntimamente relacionados entre sí. Fechas, lugares, tipo de armamento y grado de destrucción no son factores independientes. De este modo, el conocimiento de uno o dos de ellos permite, en muchos casos, deducir con suficiente grado de aproximación los que faltan. La realidad de los bombardeos sobre Madrid se presenta, así, como un gran mosaico de datos del que conocemos una parte muy apreciable de sus teselas, las cuales nos permiten plantear cómo fueron muchas otras de las teselas desaparecidas por el paso del tiempo.

\footnotetext{
${ }^{25}$ Ver nota $n^{\circ} 16$
} 


\subsection{Cronología de los bombardeos}

El desarrollo cronológico de los bombardeos sobre Madrid es algo conocido en líneas generales. Las principales monografías que tratan esta cuestión, Montoliú (2000), Solé y Villaroya (2003), Minchom (2015), Andrés (2017), Moreno-Aurioles (2016), suelen describirla someramente, relacionando, en el mejor de los casos, las fechas de algunos ataques con algunos de los edificios afectados, conocidos por la especial relevancia de estos últimos. Sólo De Vicente (2014a y 2014b) plantea una cronología que entra en detalle en cuanto a los días de los ataques, aunque incompleta en lo que se refiere a la información de los inmuebles afectados, sin duda debido a que se basa únicamente en fuentes militares, las cuales suelen referirse a zonas y no a edificios, salvo casos singulares.

Las primeras bombas fueron arrojadas por la aviación en los últimos días de agosto de 1936. Desde entonces hasta noviembre los ataques fueron esporádicos, aunque se intensificaron hacia la última semana de octubre. Por la cantidad y la potencia de las bombas utilizadas y por la táctica empleada, estos primeros bombardeos son más comparables a los ataques aéreos de la primera Guerra Mundial sobre ciudades como Londres o Venecia. En la primera semana de noviembre las fuerzas sublevadas llegaron a las puertas de Madrid por el sur y el suroeste. Las baterías de artillería tenían a tiro toda la ciudad. El día 7 de noviembre dio comienzo el intento de asalto desde las posiciones de la Casa de Campo y el primer bombardeo sistemático de una gran ciudad. Los libros de intervención de los bomberos atestiguan cómo desde las 4:00 de la madrugada los obuses empezaron a caer sobre la capital, y no sólo sobre las posiciones defensivas, que aún se mantenían en la margen meridional del Manzanares. Hasta la primera semana de diciembre, artillería y aviación se coordinaron para bombardear la población de forma casi ininterrumpida. Sólo las adversas condiciones meteorológicas de la última semana de noviembre impusieron una tregua de los bombardeos aéreos. Fracasado el primer intento de tomar la capital por las armas, los últimos bombardeos aéreos se produjeron, ya de forma esporádica entre enero y abril de 1937. La aviación sería entonces destinada a otros frentes (Guadalajara, Euskadi, etc.), pero la artillería permaneció bombardeando la ciudad casi a diario, con algunos ataques especialmente intensos, hasta febrero de 1939, poco antes de la rendición a raíz del golpe interno encabezado por el coronel Casado.

Esta investigación ha permitido reconstruir en detalle estos acontecimientos, relacionando fechas y, en muchos casos, hora de los ataques, con las zonas y los edificios afectados (Fig. 14). Pudiendo, en primera instancia, datar muchas de las imágenes disponibles, al menos de forma aproximada, gracias a las referencias de los edificios fotografiados en los libros de intervención de los bomberos.

En muchos casos, la fecha constatada de los ataques a determinados edificios ha permitido deducir la de otros adyacentes o muy próximos, considerando que se trata del mismo bombardeo, lo cual es una suposición razonable, sobre todo tratándose de bombardeos aéreos. El análisis de las horas registradas de las intervenciones de los bomberos permite deducir cierto patrón temporal o rutina en los bombardeos del mes de noviembre: con las primeras luces del día comenzaban los disparos de la artillería, cuyo rastro de humo señalaba los objetivos a la aviación, y sólo cesaban cuando hacían aparición las primeras aeronaves. Una vez éstas habían arrojado su carga, la artillería reanudaba su actividad. La aviación, procedente de los aeropuertos de Salamanca, Ávila, Navalmoral, Arenas de San Pedro y Talavera (De Vicente 2014d, 2176), solía bombardear por las mañanas las zonas próximas al frente, cuando la visibilidad era óptima, con el fin de preparar el terreno de las fuerzas atacantes: Ciudad Universitaria, Argüelles, proximidades y cornisa del río Manzanares, puente de Segovia, paseo de Extremadura, puente de Toledo, Usera, etc. A partir de las 18:30, cuando caía la noche y la visibilidad era nula, salvo la escasa iluminación de las bengalas, la aviación bombardeaba el centro de la ciudad. Se combinaban así los ataques que requerían cierto grado de precisión y que podrían considerarse de apoyo a las acciones militares en tierra y los ataques no necesariamente tan precisos, 


\section{ACE Architecture, City and Environment}

e-ISSN $1886-4805$

cuyo objetivo último era sembrar el terror y la desmoralización entre la población para inducir la rendición de los defensores ${ }^{26}$.

Figura 14. Análisis cronológico de los bombardeos
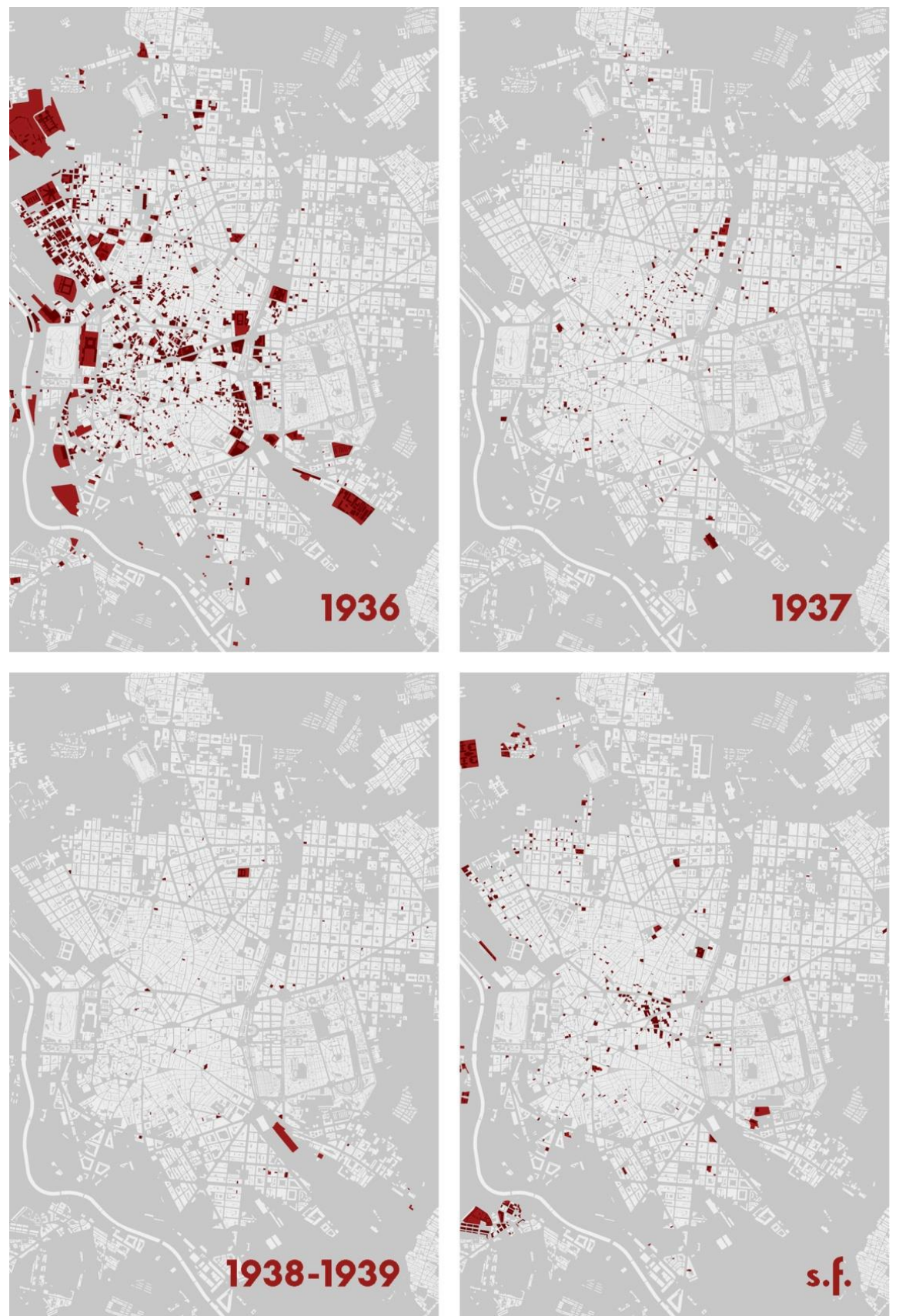

Secuencia cronológica de los edificios afectados por los bombardeos en los años 1936, 1937 y desde 1938 hasta el cese de los bombardeos en marzo de 1939. Casi la totalidad de los bombardeos del año 1936 se produjeron exclusivamente en los meses de noviembre y diciembre. El último plano refleja el 15\% de los edificios documentados de los que no se conoce ni se ha podido deducir la fecha del ataque. Fuente: elaboración propia.

\footnotetext{
26 “Además de los constantes ataques a las posiciones militares republicanas, se pretendió aterrorizar a la población madrileña para crear una desmoralización general que llevara a abandonar la defensa de Madrid. Una parte de los bombardeos aéreos, especialmente los nocturnos, estuvo dirigida contra la población civil" (De Vicente, 2014a, pág. 499).
}

ACE, 15 (43) CC BY-ND 3.0 ES | UPC Barcelona, España | Cartografiar la destrucción. Los bombardeos de la Guerra Civil 
Según delatan los libros de intervención del cuerpo de bomberos, especialmente intensos fueron los bombardeos aéreos de los días 8, 9, 16, 17, 19, y 20 de noviembre de 1936 (Figura 15); 2, 4 y 6 de diciembre; y 8 de enero de 1937. Asimismo, los bombardeos artilleros de los días 9, 17, 22 y 23 de noviembre de 1936, 4 de enero y 23 de abril de 1937. A partir de entonces se reduce la frecuencia de las intervenciones de los bomberos a consecuencia de los bombardeos. No obstante, De Vicente (2014a) destaca también como intensos los de los días 27 de abril, 7 de junio, 11 y 14 de octubre y 24 de noviembre de 1937; 3 de abril, 3 de mayo, 20 de julio, 16 y 17 de agosto, 13 y 14 de octubre y 24 de diciembre de 1938.

Figura 15. Bombardeos aéreos nocturnos correspondientes al 16 y 19 de noviembre de 1936
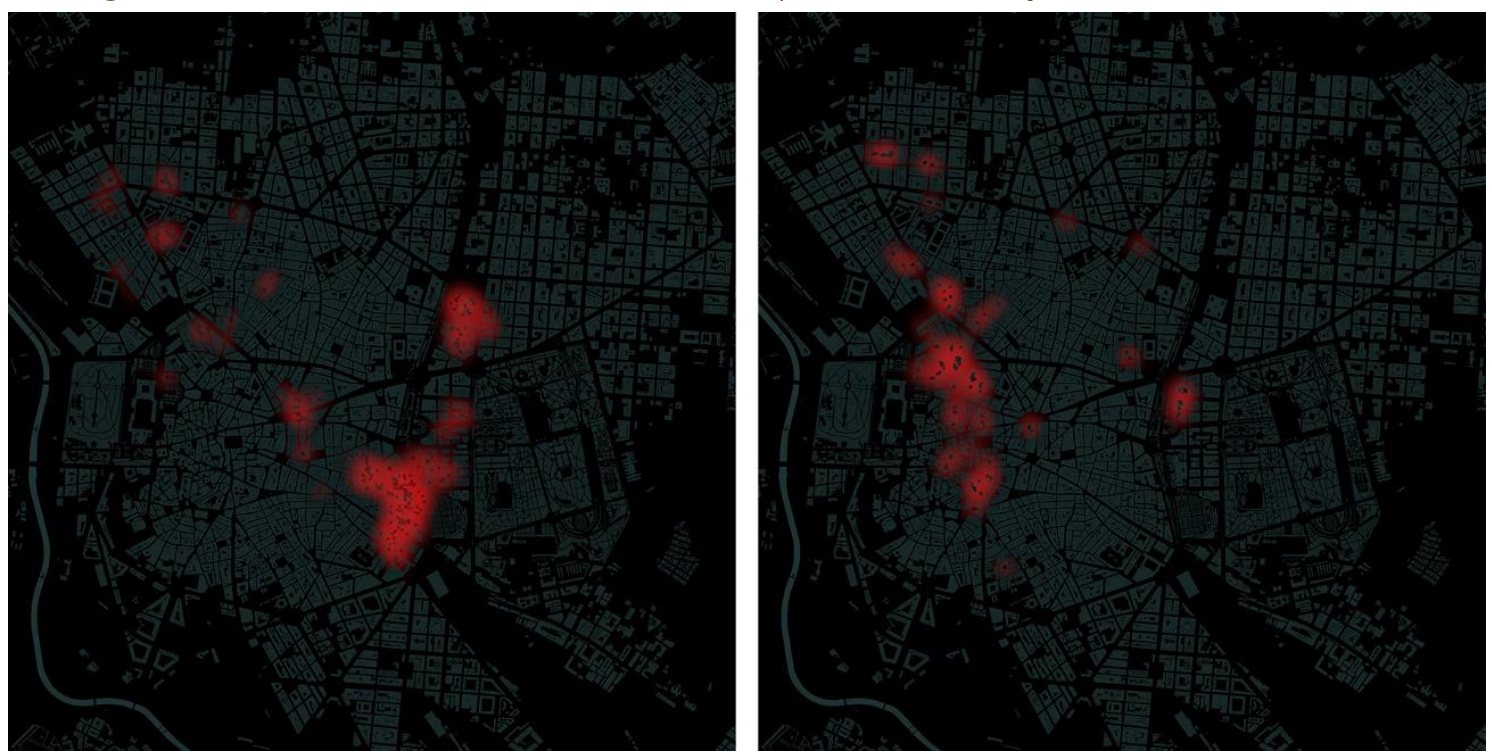

El bombardeo nocturno del 16 de noviembre (izquierda) comenzó hacia las siete de la tarde y afectó a un amplio abanico de zonas, desde el sureste de la ciudad hasta el noroeste, incidiendo con especial intensidad en el barrio de las Letras. El día 19 (derecha), a última hora de la tarde, la devastación se extendió a lo largo de una franja sensiblemente paralela al río, desde la calle de Toledo y sus inmediaciones hasta la de Rodríguez San Pedro, pasando por los ámbitos de las calles Sacramento, Mayor, Bordadores, Escalinata, Costanilla de los Ángeles, Trujillo, Bola, Torija, San Bernardo, Tutor y plaza de España. Fuente: elaboración propia.

\subsection{Identificación de patrones}

Del análisis de la distribución de los impactos, conociendo la fecha del bombardeo, se pueden extraer relaciones y deducir patrones de ataque. Especialmente en el caso de los bombardeos aéreos, los edificios dañados suelen ser colindantes o muy próximos y se agrupan en forma de racimos a lo largo de una directriz y se puede, en muchos casos, intuir la trayectoria de las aeronaves y la secuencia de las detonaciones. La mayor parte de estas trayectorias parecen alinearse en dirección aproximada norte-sur.

Podemos tomar como casos ilustrativos los de los bombardeos del 30 de octubre y 16 de noviembre de 1936 (Figura 16). El del día 30 fue un característico ataque aislado, que produjo un elevado número de víctimas ${ }^{27}$, aunque relativamente pocos daños en edificios. En principio sólo dos aeronaves, en un mismo vuelo, habrían descargado parte de sus bombas en Getafe y el resto en Madrid (Minchom, 2015, 101). Los impactos documentados se alinean, pudiéndose trazar prácticamente la trayectoria de las aeronaves. Al anochecer del 16 de noviembre, con el fin de eludir a la aviación republicana, dieron

\footnotetext{
${ }^{27}$ Las cifras de víctimas mortales de esta aciaga jornada son confusas, y varían entre los 41 muertos, según el periódico francés ParisSoir, y los 91 de las listas de la morgue municipal (Minchom, 2015).
} 
comienzo los ataques masivos. En el barrio de las Letras, la gran cantidad de edificios documentados no permite trazar una trayectoria nítida, aunque se pueden deducir cuatro directrices a lo largo de las cuales parecen agruparse los impactos. Estas directrices coinciden aproximadamente con los cursos del Paseo del Prado y de las calles de la Alameda, de San Pedro y de San Agustín. Esa misma noche, además, se arrojaron bombas incendiarias sobre el Museo del Prado, la Biblioteca Nacional y algunas calles aledañas de ambos edificios

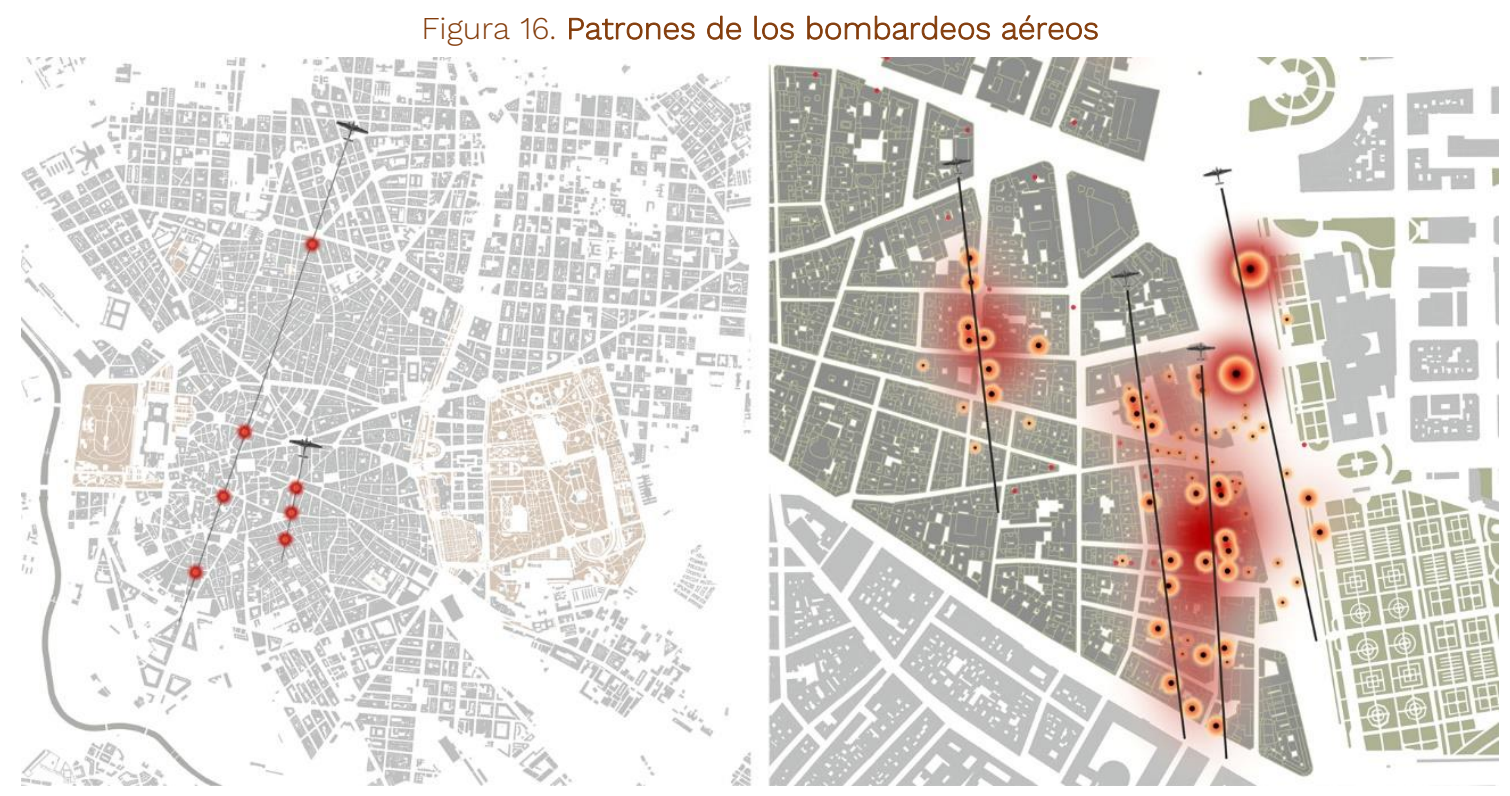

A la izquierda, bombardeo del 30 de octubre de 1936. A la derecha: bombardeo del 16 de noviembre de 1936. Detalle del ámbito del barrio de la Letras próximo al Paseo del Prado. Fuente: elaboración propia.

Frente a la concentración de los bombardeos aéreos en el tiempo y el espacio, los bombardeos artilleros, en cambio, fueron casi permanentes durante toda la guerra y afectaron prácticamente a la totalidad de la ciudad (Figura 17). La reiteración de ataques artilleros sobre los mismos ámbitos en diferentes fechas no permite suponer que la proximidad entre impactos se deba a que se trata de un mismo ataque. De modo que, salvo aquellos siniestros cuya fecha podemos conocer por la intervención de los bomberos, es difícil concretar el momento de los impactos.

Se puede afirmar que no hubo zona de la ciudad libre de impactos de artillería, aunque se ha constatado que su distribución no fue completamente uniforme en todos los barrios: hubo una densidad notablemente menor de siniestros en el barrio de Salamanca y una concentración de impactos en las zonas entre la plaza de la Moncloa y la calle del Marqués de Urquijo, así como entre las calles de Alcalá y la Gran Vía.

La mayor singularidad es la del edificio Telefónica. Observatorio militar, centro neurálgico de las comunicaciones telefónicas y refugio durante la guerra, no sólo constituía un blanco a batir por la artillería atacante, sino que, por su altura y localización, fue también un punto de referencia inmejorable para corregir el tiro en el acecho a otros objetivos de la ciudad. Los 120 impactos de cañón que sufrió el edificio fueron dibujados a mano sobre los planos de las fachadas por su arquitecto, Ignacio de Cárdenas, encargado de dirigir el mantenimiento durante la guerra (Navascués, 1984, 161). La práctica totalidad de dichos impactos se produjeron en la cubierta, en su fachada occidental, orientada justamente en dirección al cerro Garabitas, y en su fachada meridional, orientada en dirección al cerro de los Ángeles, ambos lugares donde se ubicaban las baterías de artillería.

ACE, 15 (43) CC BY-ND 3.0 ES | UPC Barcelona, España | Cartografiar la destrucción. Los bombardeos de la Guerra Civil y el patrimonio inmueble de Madrid. DOI: http://dx.doi.org/10.5821/ace.15.43.9014 
Figura 17. Impactos documentados de bombardeos aéreos (izquierda) y
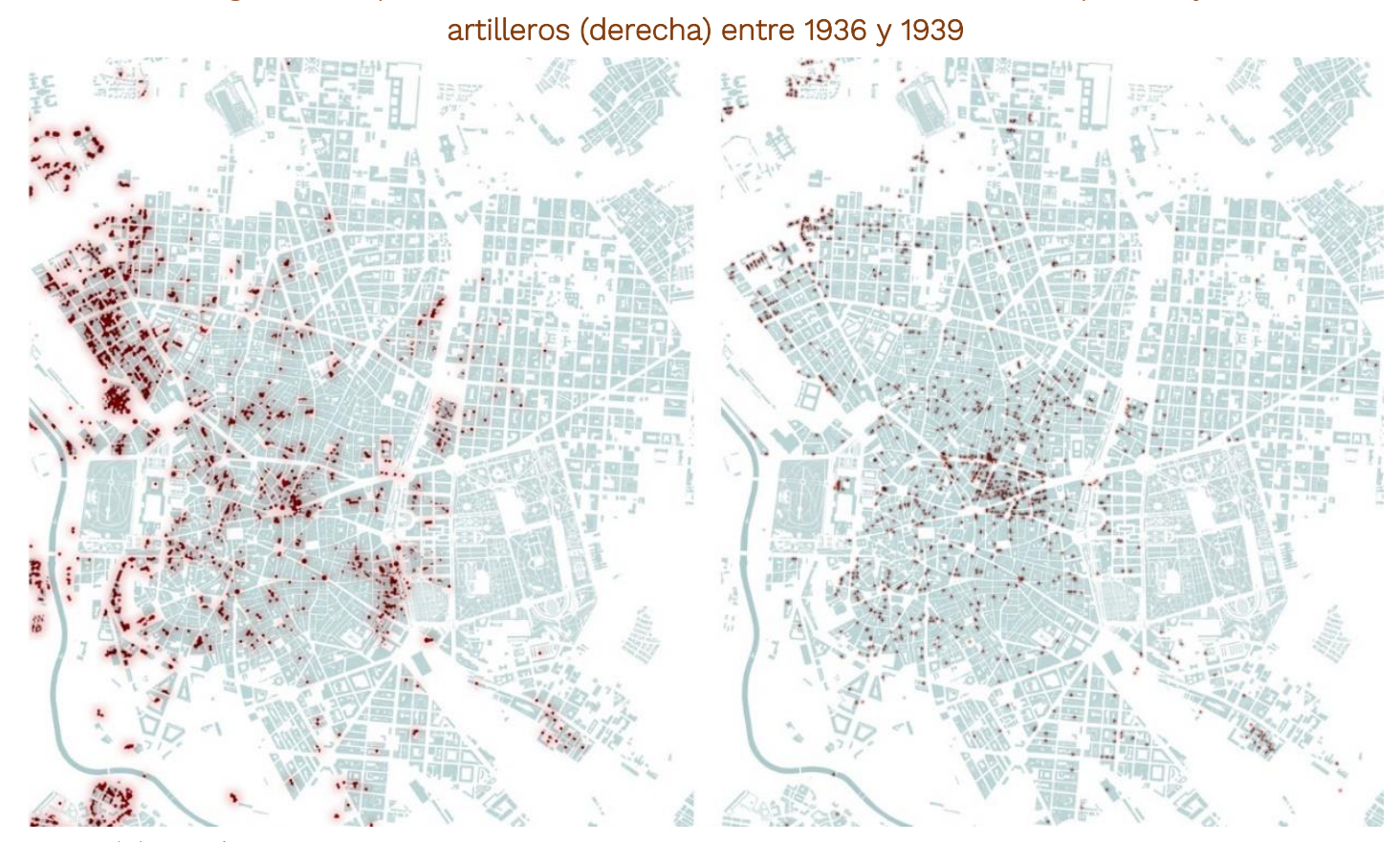

Fuente: elaboración propia.

\subsection{Tipo de armamento y grado de destrucción}

El análisis y el entendimiento del tipo de armamento empleado en los bombardeos sobre Madrid, sin entrar en detalles propios de especialistas en la materia, es pertinente por cuanto, como se ha visto, está directamente relacionado con la cronología de los acontecimientos y, sobre todo, porque las diferentes características del armamento empleado explican los efectos y el grado de destrucción provocada en el patrimonio edilicio de la ciudad.

Los obuses o proyectiles de artillería se disparaban, desde las baterías instaladas en los cerros de Garabitas, en la Casa de Campo, y de los Ángeles, a doce kilómetros al sur de la ciudad. Aunque la capacidad destructiva de los obuses variaba en función de su calibre, en general provocaban daños localizados y limitados en los elementos constructivos: boquetes de mayor o menor tamaño en fachadas, cubiertas, forjados o pavimentos de vías públicas (Figura 18). No obstante, para comprender la extensión del efecto provocado por los bombardeos artilleros sobre la ciudad es preciso apuntar la cantidad de proyectiles lanzados: "Los partes republicanos estimaban que un bombardeo artillero enemigo, sobre el casco de Madrid, era importante cuando superaba los seiscientos disparos realizados en un mismo día. Hay que destacar que una media de la actividad artillera normal de los nacionales, sin grandes bombardeos, era del orden de los cuatrocientos a quinientos disparos decenales; es decir, unos cuarenta o cincuenta cada día." (De Vicente, 2014a, pág. 196)

En cuanto a las bombas arrojadas desde aviones, eran básicamente de dos tipos: explosivas o incendiarias. La capacidad destructiva de las primeras variaba también en función de su carga. Hasta noviembre de 1936 solían emplearse de 10 kg., una potencia reducida como para provocar daños graves en edificios ${ }^{28}$. En noviembre y diciembre de 1936 y enero de 1937 se emplearon bombas de 50,

\footnotetext{
${ }^{28}$ Es necesario insistir en que este estudio no analiza las consecuencias personales de los bombardeos. La explosión de una bomba de $10 \mathrm{~kg}$. podía matar o herir gravemente a transeúntes u ocupantes de un inmueble, aunque los daños en los propios edificios se puedan calificar de poco graves. Con la misma lógica han de entenderse los efectos de los miles de obuses de artillería lanzados contra la población.
}

ACE, 15 (43) CC BY-ND 3.0 ES | UPC Barcelona, España | Cartografiar la destrucción. Los bombardeos de la Guerra Civil 


\section{ACE Architecture, City and Environment}

100 y 250 kg., potencias explosivas suficientes como para destruir total o parcialmente un edificio, o como para producir grandes cráteres en las calles (Figura 19).

Figura 18. Efectos de los impactos de proyectiles de artillería en los edificios de Madrid.
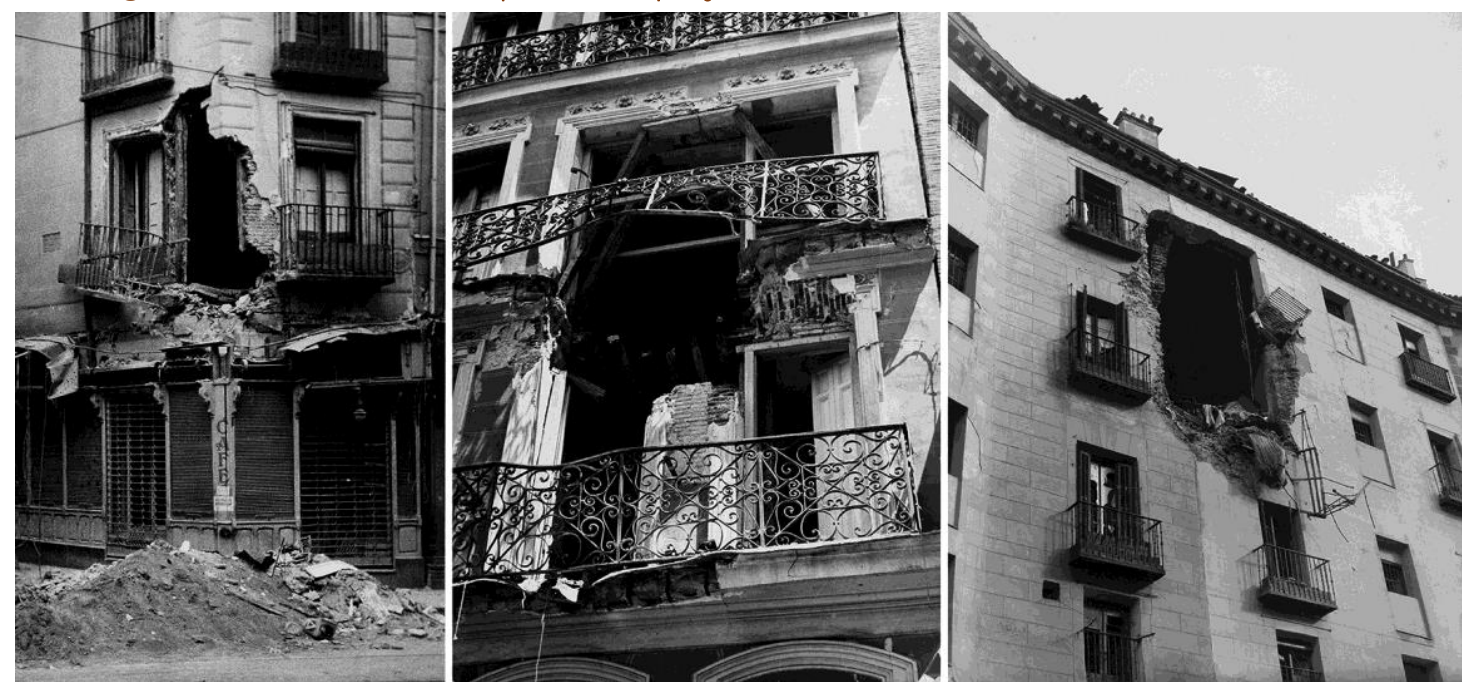

Izquierda: calle de la Montera ำ32, esquina calle de los Jardines. Centro: calle de la Victoria ㄲo7. Derecha: calle de la Cava de San Miguel №13 y 15. Fuente: Biblioteca Nacional de España.

Figura 19. Efectos de bombas de aviación en los edificios y calles de Madrid.
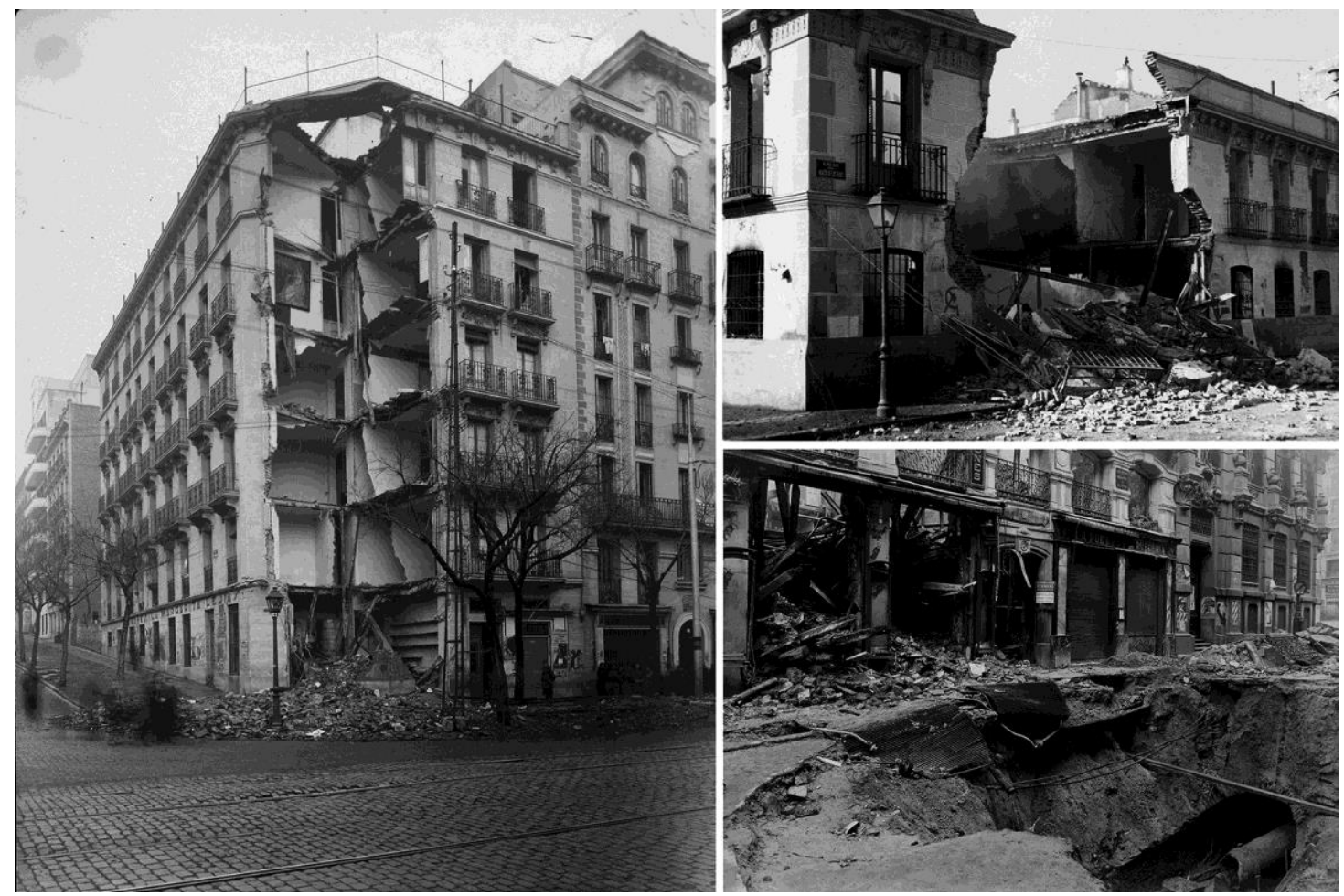

Izquierda: edificio de la avenida de la Ciudad de Barcelona №17, bombardeado el 23 de noviembre de 1936. Derecha arriba: edificio de la calle del Buen Suceso nำ4, esquina Martín de los Heros, bombardeado probablemente el 6 de diciembre de 1936. Derecha abajo: cráter en la Carrera de San Jerónimo y edificio no7 de la misma vía. Fuente: Biblioteca Nacional de España.

ACE, 15 (43) CC BY-ND 3.0 ES | UPC Barcelona, España | Cartografiar la destrucción. Los bombardeos de la Guerra Civil 


\section{ACE Architecture, City and Environment}

Las bombas incendiarias pesaban entre 2 y $5 \mathrm{~kg}$ y generaban temperaturas de hasta 3.000 en uno o varios focos. Se arrojaban gran cantidad de una sola vez para garantizar numerosos focos de incendio en la mayor cantidad posible de inmuebles. En una ciudad como el Madrid de los años treinta la gran mayoría de los edificios estaban construidos con soluciones tradicionales: estructura vertical de pies derechos de madera con relleno de ladrillo, forjados de vigas y viguetas de madera y tejado inclinado con estructura también de madera. La probabilidad de que estas bombas provocaran grandes incendios difíciles de extinguir era muy elevada. No obstante, la gravedad de los daños provocados por las bombas incendiarias variaba mucho en función de diferentes factores: la densidad de edificación de las zonas bombardeadas, el tipo y configuración de las cubiertas donde caían, la intervención más o menos rápida del cuerpo de bomberos o de los mismos habitantes para extinguir el fuego y, en no pocas ocasiones, la aleatoriedad de la suerte. Cuando todos estos factores jugaron favorablemente, como en los casos del Museo del Prado y la Biblioteca Nacional, los daños fueron anecdóticos. En otros donde las circunstancias se conjuraron en contra, la destrucción de los edificios fue casi total: el palacio de Liria, el edificio n10 de la Puerta del Sol, la antigua Diputación Provincial, el mercado y algunos edificios de la plaza del Carmen, etc. (Fig. 20). Entre estos dos extremos se dio una amplia casuística: hubo multitud de edificios cuyas cubiertas y última planta fueron total o parcialmente destruidas por efecto del fuego.

Además, en Madrid se empezó a experimentar con la combinación de diferentes tipos de bombas, explosivas e incendiarias, con el fin de comprobar la capacidad de las segundas para potenciar el efecto destructivo de las primeras. En este caso, definido como "bombardeo mixto completo" según De Vicente (2014b, págs. 2410-2411), cada avión alemán Junker descargaba 8 bombas de 50 kg, 32 bombas de $10 \mathrm{~kg}$ y 282 bombas incendiarias.

Figura 20. Efecto de las bombas incendiarias en los edificios de Madrid.
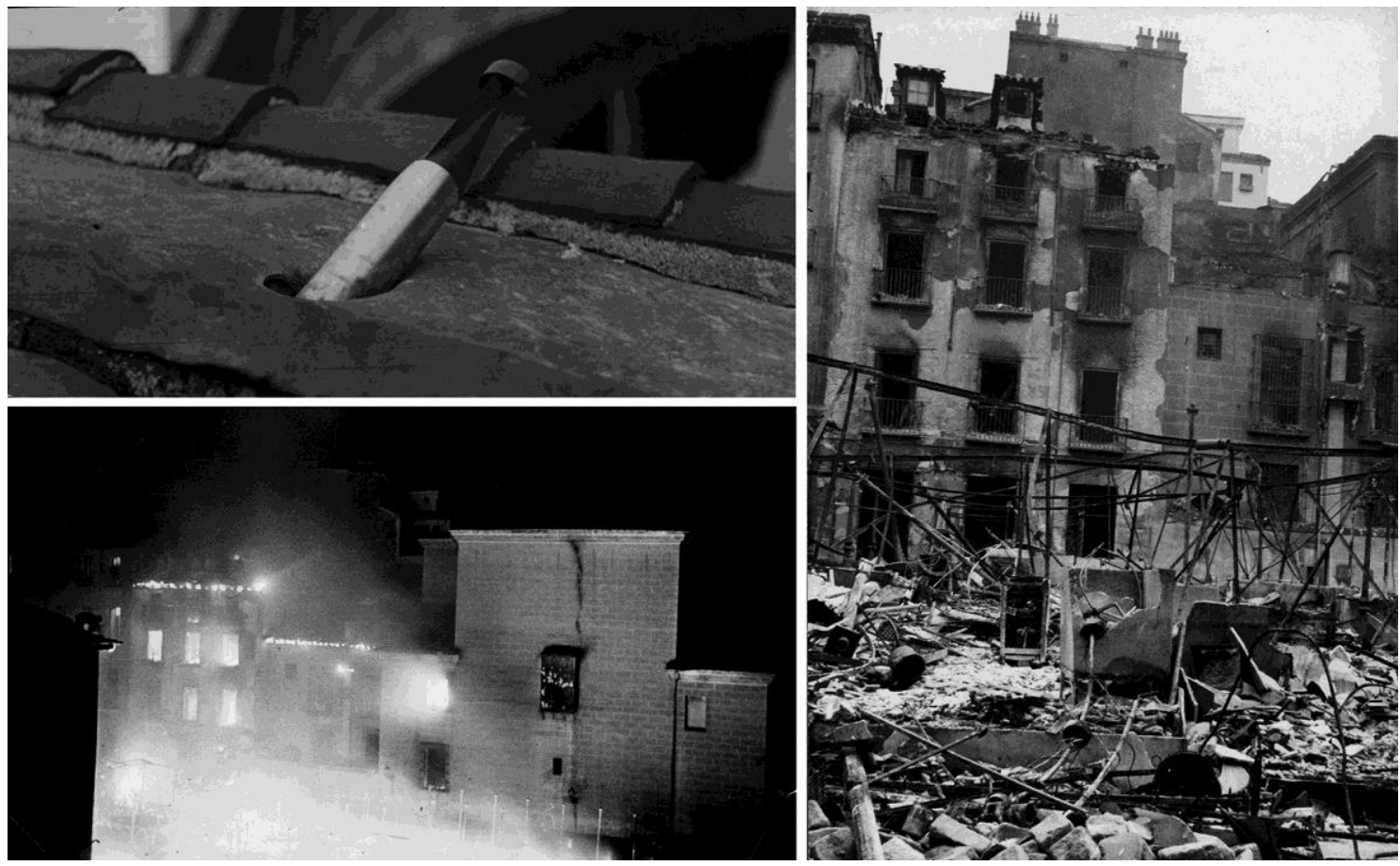

Arriba: bomba incendiaria que no llegó a explotar el 16 de noviembre de 1936, incrustada en la cubierta de plomo del Museo del Prado. Abajo y derecha: destrucción del mercado y otros edificios de la plaza del Carmen a consecuencia del incendio provocado por las bombas incendiarias arrojadas el 17 de noviembre de 1936. Fuente: Biblioteca Nacional de España. 
Dada la heterogeneidad en la intensidad de los daños producidos en los edificios, que varía desde daños superficiales hasta la destrucción total, se hace imprescindible un análisis de este factor, pues el mero señalamiento de edificios afectados es un parámetro insuficiente que puede dar lugar a una comprensión equívoca o simplista de la intensidad de destrucción de la ciudad. Proponemos una escala cualitativa para definir el grado de afectación de los edificios dañados, tomando como referentes las escalas empleadas en los estudios del CRRSM y en los Bomb Damage Maps ${ }^{29}$ :

1) Destruido: designa edificios completamente destruidos o de los que sólo permanecen en pie elementos aislados como muros o paños de fachada. Es el caso de edificios alcanzados por bombas de aviación de gran potencia (250 Kg.) o que han sufrido grandes incendios.

2) Semidestruido: designa edificios cuya estructura ha sido gravemente dañada, aunque el edificio pueda permanecer parcialmente en pie. Este suele ser el caso de edificios alcanzados por bombas de aviación de potencia media (50-100 kg.).

3) Afectado: designa edificios con daños graves pero puntuales o muy localizados y de fácil reparación, generalmente debidos al impacto de obuses, granadas de artillería o bombas incendiarias que hayan provocado incendios controlados (boquetes en fachadas o paños de forjados, cubiertas incendiadas, etc.)

4) Ligeramente afectado: designa edificios con daños superficiales por efecto de la metralla o la onda expansiva (desconchones, carpinterías reventadas, vidrios rotos, etc.)

5) Sin datos: designa edificios afectados de los que no es posible determinar el grado de afectación con la información actualmente disponible.

La asignación de un grado de la escala a un edificio sólo ha sido posible cuando se ha dispuesto de documentación fotográfica que permitiera una evaluación visual de los daños del edificio o, singularmente, si hemos dispuesto de información descriptiva. Dado que de muchos de los edificios afectados no existe documentación fotográfica directa o no se pueden apreciar los daños en las imágenes del vuelo de 1941, cabe deducir que casi todos los edificios en los que no se ha podido determinar el grado de afectación, los daños debieron de ser muy localizados o fácilmente reparables. Como en cualquier escala cualitativa, hay casos en los que la asignación de un edificio a uno u otro grado no es inequívoca, quedando un inevitable margen para la interpretación y el buen criterio del investigador.

A su vez, como el alcance de los daños producidos está íntimamente relacionado con las características de las armas utilizadas, especialmente su carga explosiva, a partir de las imágenes fotográficas analizadas, se pueden plantear hipótesis del tipo de ataque sufrido.

Se comprueba en el análisis (Figura 21) que, en relación a la cantidad de edificios afectados y a la extensión de los ataques, la proporción de edificios total o parcialmente destruidos es baja ${ }^{30}$ y su distribución coincide, según las hipótesis, con las zonas que sufrieron bombardeos aéreos intensos y, por tanto, donde se emplearon mayor cantidad de bombas con mayor capacidad destructiva. La mayor parte, dos de cada tres edificios afectados documentados, sufrieron daños muy localizados y, por tanto, de fácil reparación.

\footnotetext{
29 La escala del parcelario con el estado de las fincas del CRRSM establecía los siguientes grados: destruida, semidestruida buenas condiciones, semidestruida malas condiciones, afectada, ligeramente afectada e indemne. La distinción en dos clases para las edificaciones semidestruidas probablemente respondía a un criterio de seguridad de las personas en cuanto a la posibilidad de que se produjeran derrumbamientos que pudieran causar más víctimas.

La escala de los Bomb Damage Maps establecía una graduación más detallada que atendía a las posibilidades de reparación de los edificios afectados, clasificándolos en: total destruction, damaged beyond repair, seriously damaged - doubtful if repairable, seriously damaged - repairable at cost, general blast damage - not structural y blast damage - minor in nature.

30 Según las categorías planteadas, en relación a la cantidad de edificios afectados documentados, podemos computar 210 edificios destruidos (11,88\%), 300 semidestruidos (16,98\%), 271 con daños localizados (15,34\%), 97 con daños superficiales $(5,49 \%)$ y $900(50,31 \%)$ sin datos para valorar
} 
Figura 21. Análisis gráfico de la intensidad de la destrucción provocada por los bombardeos sobre Madrid

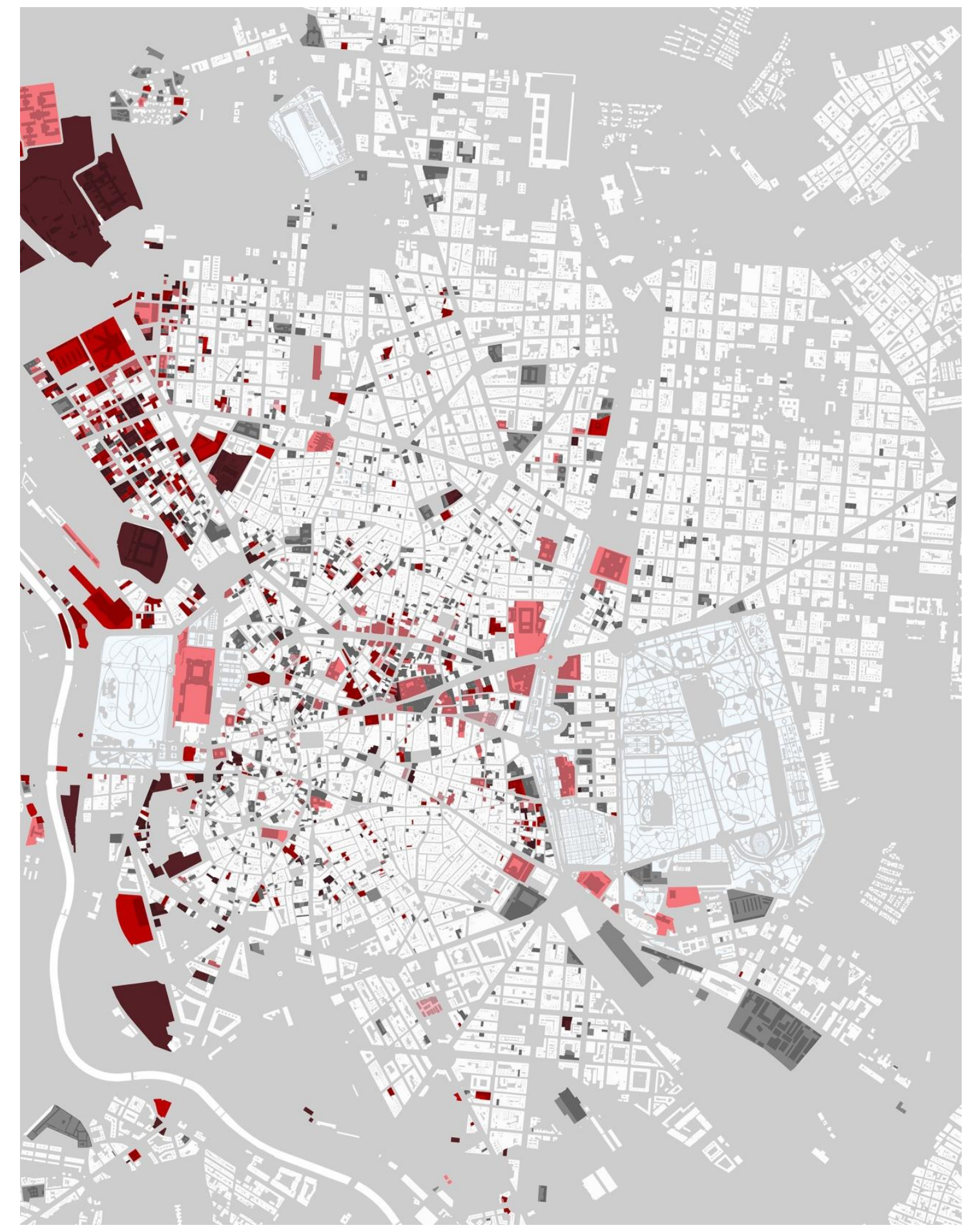

La gradación de luminosidad en los tonos rojos indica las diferentes categorías consideradas, desde los edificios destruidos (tonalidad más oscura) hasta los ligeramente afectados (tonalidad más clara). En tono gris se indica los edificios de los que desconocemos en qué medida resultaron afectados. Fuente: elaboración propia.

\footnotetext{
ACE, 1.5 (43) CC BY-ND 3.0 ES | UPC Barcelona, España | Cartografiar la destruccion
y el patrimonio inmueble de Madrid. DOI: http://dx.doi.org/10.5821/ace.15.43.9014
} 


\subsection{Usos de la edificación afectada}

Recientes estudios publicados, en el caso de Madrid, parecen motivar la mayor parte de los bombardeos sufridos desde cierta lógica exclusivamente militar, dada la existencia en la ciudad de muchos edificios cuyo uso durante la guerra podía atribuirse a una finalidad militar directa o indirecta. A partir de los sucesivos listados de objetivos en Madrid redactados por los mandos sublevados, De Vicente (2014a) señala que se consideraban como tales no sólo cuarteles, edificios militares en sí, posibles observatorios o posiciones de baterías de artillería, sino también escuelas e iglesias destinadas a polvorines o alojamiento de soldados, fábricas, gasolineras, sedes de sindicatos y milicias, ministerios y edificios gubernamentales, parques de bomberos, cocheras de tranvías, centrales de servicios, depósitos de agua, mercados, hospitales, etc. Estos objetivos, distribuidos por toda una ciudad, militarizada en la práctica por su condición de sitiada, podrían justificar por sí mismos el bombardeo de casi cualquiera de sus ámbitos urbanos lo cual, por otro lado, parece responder a la lógica de la guerra total que también se puso en práctica en Madrid. Sin embargo, a partir del estudio realizado, resulta que sólo un 3\% de los edificios dañados documentados pueden considerarse objetivos militares según los propios criterios de las fuerzas atacantes. Casi un 10\% eran edificios de uso público, menos del 3\% de uso industrial y el 85\% restante eran edificios de viviendas (Figura 22).

\section{Conclusiones}

Los autores que han escrito sobre los bombardeos de Madrid durante la Guerra Civil Española coinciden en señalar tres motivos que concurrieron, en mayor o menor proporción, para que, en noviembre de 1936, se produjera el primer bombardeo moderno sobre una gran ciudad europea: como estrategia de apoyo a las operaciones militares de las unidades de tierra; como estrategia para inducir la rendición de los defensores mediante el terror, el amedrentamiento y la desmoralización de los habitantes de la ciudad; y como campo de prueba para ensayar con fuego real la tecnología armamentística de última generación con la mirada puesta en la guerra que se avecinaba en Europa. El resultado de esta investigación arroja un total de más de 1.900 edificios y espacios públicos afectados documentados, que ocupan casi 300 hectáreas de suelo urbano ${ }^{31}$. A pesar de que ninguna zona de la ciudad quedó completamente a salvo de las bombas, la distribución o densidad de esa destrucción no es uniforme. Se aprecia una evidente concentración de impactos en una franja de ciudad de entre 1.400 y 1.600 metros paralela al río Manzanares; en otra franja a lo largo del Paseo del Prado y sus inmediaciones; y en una tercera zona, en el mismo centro de la ciudad, entre la Puerta del Sol y la Gran Vía. El resto de la población resultó afectada de forma menos intensa, pudiendo corroborar empíricamente en esta investigación un dato aludido en numerosos estudios previos, a saber, la casi nula densidad de ataques sufridos en el barrio de Salamanca, al este de la calle de Serrano ${ }^{32}$.

Dado el primordial objetivo de esta investigación, es decir, la comunicación por medios gráficos de la destrucción del patrimonio urbano y arquitectónico de Madrid a consecuencia de los bombardeos, cabría decir que el principal resultado de la misma no son tanto las conclusiones que podamos expresar por escrito, sino, sobre todo, los dibujos realizados, la cartografía de los bombardeos y de

\footnotetext{
${ }^{31}$ Ambas cifras, 1.897 edificios y 45 vías públicas, o 293,7 hectáreas de suelo afectados, sirven para cuantificar de dos maneras diferentes la magnitud del urbicidio de Madrid (ver nota $n^{\circ} 3$ ). No obstante, hay que precisar que la primera de ellas no contempla que no todos los edificios afectados tenían la misma envergadura, ni resultaron destruidos en la misma medida, como se ha visto en el análisis realizado. Por otro lado, al haber contabilizado las superficies de las parcelas catastrales de los edificios afectados, en la superficie urbana afectada no se ha computado la superficie afectada de espacio o vías públicas.

${ }^{32}$ No es este lugar para buscar las causas de esta circunstancia que este estudio contribuye a ratificar. Numerosas publicaciones han planteado los porqués. Una de las más recientes, que trata específicamente la cuestión de la zona neutral, es la de Moreno-Aurioles (2016).
}

ACE, 15 (43) CC BY-ND 3.0 ES | UPC Barcelona, España | Cartografiar la destrucción. Los bombardeos de la Guerra Civil 


\section{ACE Architecture, City and Environment}

sus efectos sobre el patrimonio inmueble de Madrid, que permite visualizar, comprender y conocer más en profundidad unos acontecimientos cruciales de su historia reciente (Figura 23).

Figura 22. Usos de los edificios afectados por los bombardeos sobre Madrid entre 1936 y 1939.

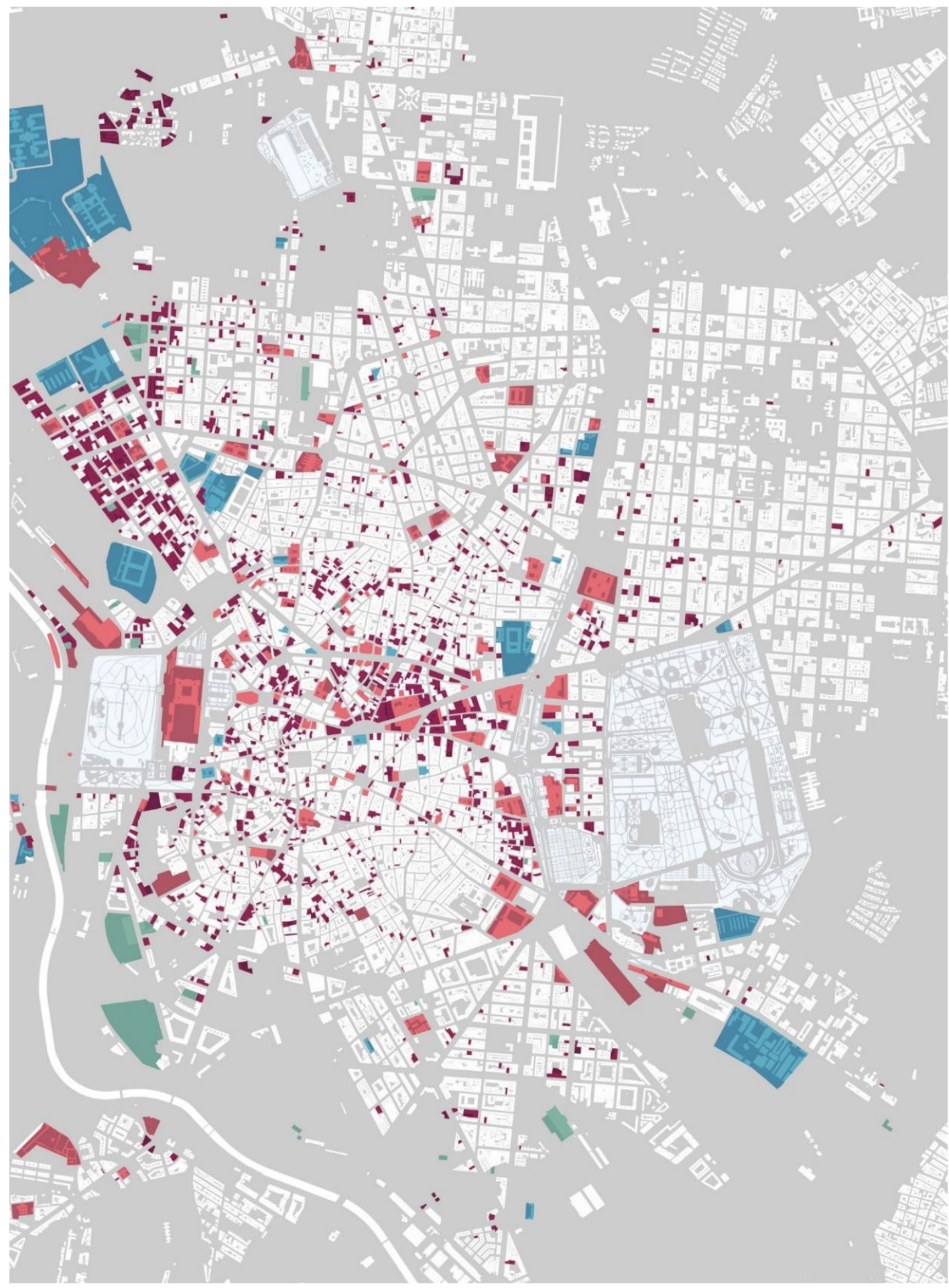

En tono azul se indican los edificios afectados con uso exclusivamente militar durante la guerra; en verde los edificios afectados con uso industrial; y en rojo los edificios públicos (tonalidad clara) y viviendas (tonalidad oscura). Fuente: elaboración propia.

ACE, 15 (43) CC BY-ND 3.0 ES | UPC Barcelona, España | Cartografiar la destrucción. Los bombardeos de la Guerra Civil 


\section{ACE Architecture, City and Environment}

Esta cartografía, resultado de un trabajo previo de documentación y análisis de datos no sólo identifica casi dos mil edificios afectados en mayor o menor medida por esos bombardeos. También permite alcanzar conclusiones significativas sobre un conjunto de parámetros que explican aquellos acontecimientos: desarrollo temporal, localización y zonificación de los siniestros, tipo de edificios afectados, tipo de armamento empleado, características y valoración de la destrucción provocada. Al mismo tiempo, se evidencian las estrechas relaciones existentes entre estos parámetros.

Figura 23. Bombardeos sobre Madrid entre 1936 y 1939 y edificios afectados

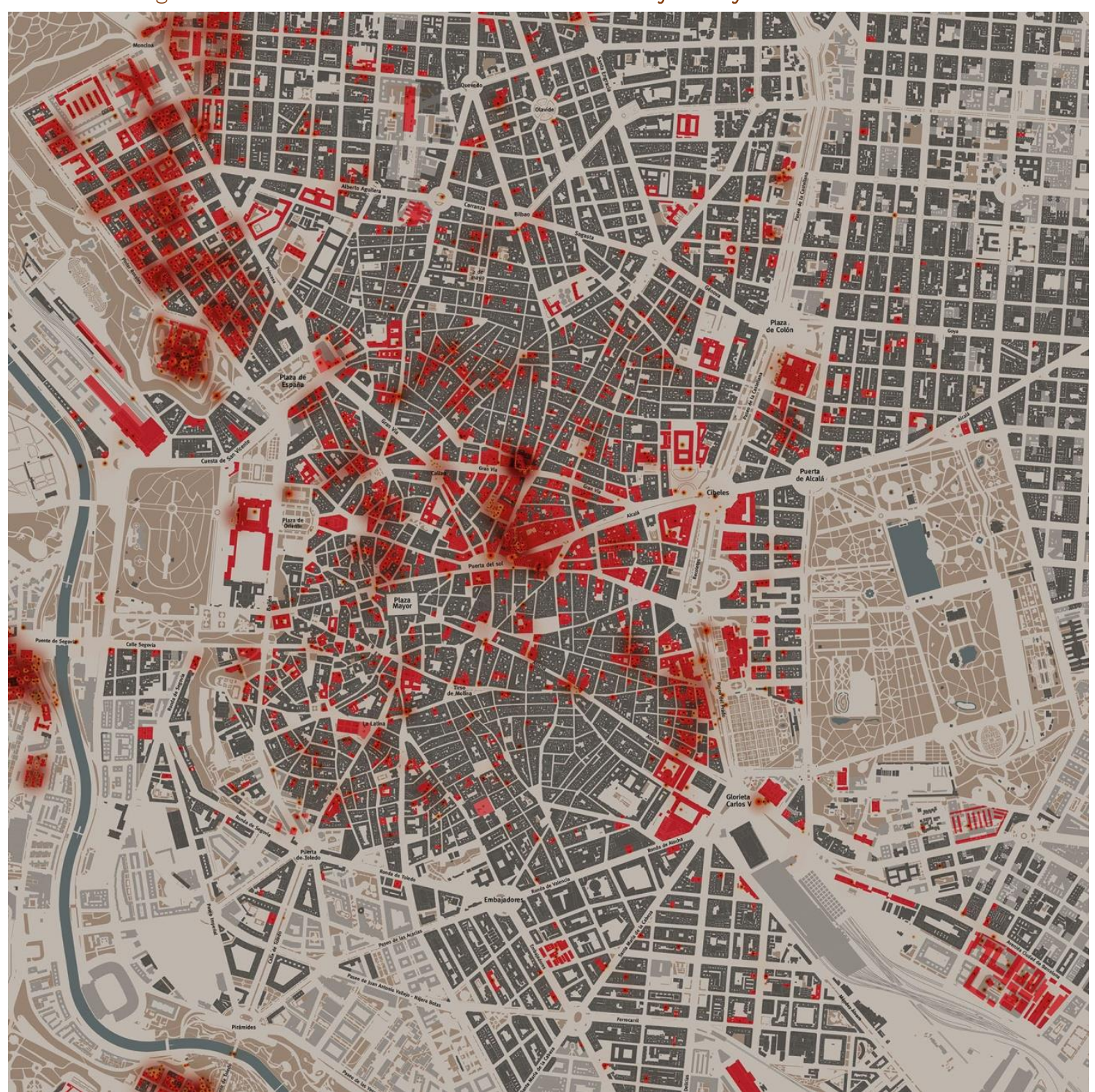

Fuente: elaboración propia.

Conscientes de la polémica que todo lo relacionado con la Guerra Civil Española aún suscita en amplios sectores sociales, en este trabajo hemos hecho especial énfasis en el aspecto metodológico y en la procedencia y fiabilidad de las fuentes documentales empleadas. En el caso concreto de Madrid es preciso destacar que todas las fuentes documentales encontradas son incompletas y muy heterogéneas, tanto por la cantidad como por el tipo de información que aportan, aunque, el hecho de que muchos de los inmuebles se encuentran documentados en más de una fuente corrobora la

ACE, 15 (43) CC BY-ND 3.0 ES | UPC Barcelona, España | Cartografiar la destrucción. Los bombardeos de la Guerra Civil 
fiabilidad de todas ellas y permite considerarlas complementarias entre sí. Ya se trate de registros del cuerpo de bomberos, listas de inmuebles dañados, planos, dibujos, colecciones de fotografías o crónicas, ninguna de ellas contiene más que una parte, más o menos representativa, de la información sobre la destrucción sufrida por la ciudad. Consecuencia de ello es la discrepancia entre la cantidad de inmuebles afectados documentados en esta investigación, más de 1.900, y los siniestros referidos de las estadísticas del Comité de Reforma, Reconstrucción y Saneamiento de Madrid (CRRSM, 1938). La mayoría de los siniestros, por tanto, no se han podido documentar. Este déficit de información se explica, en parte, por la magnitud y extensión de los ataques, frente a la limitación de medios humanos y tecnológicos disponibles en tal situación de caos y emergencia. Hay también otra explicación, compatible con la anterior, en la hipótesis de que la mayor parte de los siniestros no documentados provocaran en los inmuebles daños de escasa entidad. Dando por buena esta hipótesis habría que decir que se ha podido documentar tan solo una parte de la gran cantidad de edificios afectados, pero la mayor parte de la destrucción provocada. Hay que constatar, en cualquier caso, que los resultados de esta investigación resultan conservadores. A su vez, todas estas reflexiones obligan a considerar éste un trabajo abierto, susceptible de ser ampliado y completado en la medida en que nuevos documentos aporten información de la que, hasta ahora, no hemos dispuesto.

Otra consecuencia de la heterogeneidad de las fuentes es que la información que se ha podido encontrar de cada edificio raramente responde al conocimiento completo de los parámetros planteados (localización, fecha, tipo de ataque y daños provocados). Sin embargo, dada la relación comprobada entre dichos parámetros, en algunos casos se han podido deducir con una aproximación razonable a partir de los otros datos conocidos y del análisis de toda la información en su conjunto. Asumiendo que estas estimaciones pueden adolecer de cierto grado de imprecisión en el ámbito específico de cada edificio, contemplado singularmente, en cambio en el conjunto de la ciudad se puede considerar que el resultado refleja estadísticamente la realidad estudiada.

Paralelamente, todo el proceso de análisis de los documentos consultados y de la información obtenida ha permitido localizar y datar numerosas fotografías históricas, lo cual redunda en un mayor conocimiento sobre las fuentes mismas que se conservan actualmente en los fondos fotográficos de los archivos consultados.

La elaboración de una base de datos a partir de la información documentada es otra aportación significativa pues no sólo ha sido un medio de análisis de este estudio sino que prepara también el camino a otros futuros análisis que permitan profundizar en aspectos diferentes hasta ahora poco considerados, como son las consecuencias de los bombardeos sobre la trama urbana actual, las huellas de aquellos bombardeos que aún persisten en la ciudad, para comprobar, al menos en el caso de Madrid, en qué medida la arquitectura y la forma urbana actuales son consecuencia del conflicto armado más reciente de su historia. Esta misma base de datos y su georreferenciación abre también la puerta al uso de plataformas digitales, tecnologías móviles y realidad ampliada para acercar al público en general este conocimiento, mediante la elaboración de planos interactivos que permitan la consulta in situ de datos, imágenes o referencias documentales de un determinado edificio o entorno.

Naturalmente, la cuestión de los bombardeos sobre Madrid es tremendamente amplia y compleja, y la investigación realizada no pretende agotarla sino profundizar en su conocimiento, documentar y definir el dónde, el cuándo y el cómo, y servir de plataforma para abordar en futuros estudios el por qué y muchas otras facetas. Facetas tales como las víctimas, muertos y heridos, la defensa antiaérea, los refugios, el papel que jugaron las estaciones y túneles del metropolitano, las evacuaciones de la población, la conocida como zona neutral, el papel de las embajadas y los diplomáticos extranjeros, etc., que se relacionan directamente con el presente estudio, pero rebasan con mucho las 
posibilidades de un artículo. El interés y la pertinencia de este trabajo se nos antoja evidente, no sólo desde el punto de vista del especialista historiador, arquitecto o urbanista de Madrid, sino también a nivel divulgativo y social, dado el creciente interés que se está demostrando en medios de comunicación, publicaciones y redes sociales por la recuperación de la memoria histórica. Una memoria cuyas páginas, en este caso como en tantos otros, están pendientes de ser escritas.

\section{Autoría}

Todos los autores firmantes han participado en el proceso de documentación, elaboración de una base de datos del objeto de estudio, tratamiento gráfico de la información y redacción del presente artículo.

Conflicto de intereses: Los autores declaran que no hay conflicto de intereses.

\section{Bibliografía}

Albertí, S. y Albertí, E. (2004). Perill de bombardeig! Barcelona sota les bombes (1936-1939). 2a Edición. Barcelona, España: Albertí Editor, S.L.

Andrés, M. (2017). Arquitectura perdida. Madrid (1931-1939). Madrid, España: Editorial Y.

Arañó, L. y Capdevila, M. (2018). Topografia de la destrucció. Els bombardeigs de Barcelona durant la Guerra Civil (1936-1939). Barcelona, España: Ajuntament de Barcelona.

Barea, A. (1977). La forja de un rebelde. La llama. Madrid, España: Ediciones Turner.

Blasco, C. y Goitia, A. (2014). Viaje al infierno madrileño: los desastres de la guerra. En Actas del XV Congreso Internacional de Expresión Gráfica Arquitectónica (pp. 135-143). Las Palmas de Gran Canaria, España: ULPGC.

Bustamante, R. (1996). La conservación del Patrimonio Cultural Inmueble durante conflictos armados internos: La Guerra Civil Española 1936-1939 (Tesis doctoral). Universidad Politécnica de Madrid, Madrid.

Clavet, H. (1937). Madrid en sangre (10 meses de horror). Buenos Aires, Argentina: Routledge.

Comité de Reforma, Reconstrucción y Saneamiento de Madrid (1938). Memoria. Madrid 1937-1938. Madrid, España: Ayuntamiento de Madrid.

Coward, M. (2009). Urbicide. The politics of urban destruction. Oxon, Gran Bretaña: Ediciones Clot.

Cuarental, E. (1992). El nido de la Paloma. Madrid, España: Ediciones El Museo Universal.

Chueca, F. (1996). Retazos de una vida. Recuerdos de la guerra. Madrid, España: CIE Dossat 2000.

ACE, 15 (43) CC BY-ND 3.0 ES | UPC Barcelona, España | Cartografiar la destrucción. Los bombardeos de la Guerra Civil 33 y el patrimonio inmueble de Madrid. DOI: http://dx.doi.org/10.5821/ace.15.43.9014 
De las Heras, B. (2014): Retratando el Madrid de la Guerra Civil. Santos Yubero en el Archivo Regional de la Comunidad de Madrid. Revista General de Información y Documentación, 24(2), 343-371. DOI: https://doi.org/10.5209/rev RGID.2014.v24.n2.47404

De las Heras, B. (2015). Fotografiar una ciudad sitiada. Madrid, 1936-1939. Madrid, España: Instituto de Cultura y Tecnología, Universidad Carlos III de Madrid.

De Vicente González, M. (2014a). Historia militar de la Guerra Civil en Madrid. Los bombardeos y sus consecuencias (Tomo III). Madrid, España: Ministerio de Defensa.

De Vicente González, M. (2014b). Fuentes primarias, documentales y gráficas para una historia militar de Madrid durante la Guerra Civil 1936-1939. Madrid, España: Ministerio de Defensa.

Délano, L. E. (1937). Cuatro meses de guerra civil en Madrid. Santiago de Chile, Chile: Panorama.

Docherty, H. (20 de mayo de 2014): Second world war in Google Street View. The Guardian. Recuperado de www.theguardian.com/cities/gallery/2014/may/20/second-world-war-google-streetview-nazis-paris-london-blitz

Docherty, H. (16 de octubre de 2014): First world war in Google Street View. The Guardian. Recuperado de https://www.theguardian.com/cities/gallery/2014/oct/16/first-world-war-google-street-view

Douhet, G. (1921). Il dominio dell'aria. Roma, Italia: L'Amministrazione Della Guerra.

Fogo, J. C. (2012). Madrid y los desastres de la guerra de 1936-39: retrato de la ciudad a través de la vanguardia literaria y arquitectónica de la época. En Prieto, J. M. (coordinador), Poéticas urbanas. Representaciones de la ciudad en la literatura (pp. 331-380). Monterrey, México: Universidad Autónoma de Nuevo León.

Kindelán, A. (1982). Mis cuadernos de guerra. Barcelona, España.

Koltsov, M. (2009). Diario de la guerra de España. Barcelona, España: Editorial Planeta.

Liddell, B. H. (1925). Paris or the future of War. Londres, Reino Unido.

Lindqvist, S. (2002). Historia de los bombardeos. Madrid, España: Turner Publicaciones, S. L.

Martínez, A. y Muñoz, M. J. (2016). El Dibujo: método y conclusión en la Investigación en Arquitectura. En Actas del 16 Congreso Internacional de Expresión Gráfica Arquitectónica (Tomo II, pp. 1061- 1067). Alcalá de Henares, España: Universidad de Alcalá.

Minchom, M. (2010). From Madrid to Guernica: Picasso, Louis Delaprée and the bombing of civilians, 1936-1937. The Volunteer. Recuperado de http://www.albavolunteer.org/2010/11/from-madrid-toguernica-picasso-louis-delapree-and-the-bombing-of-civilians-1936-1937/

ACE, 15 (43) CC BY-ND 3.0 ES | UPC Barcelona, España | Cartografiar la destrucción. Los bombardeos de la Guerra Civil 34 y el patrimonio inmueble de Madrid. DOI: http://dx.doi.org/10.5821/ace.15.43.9014 
Minchom, M. (2015). Spain's Martyred Cities. From the Battle of Madrid to Picasso's Guernica. Eastbourne, Gran Bretaña: Sussex Academic Press.

Montoliú, P. (2000). Madrid en la Guerra Civil. La Historia. Volumen I. Madrid, España: Sílex.

Morcillo, G. (2011). El bombardeo artillero sobre Telefónica. Frente de Madrid: boletín trimestral de GEFREMA, (20), 12-16.

Moreno-Aurioles, J. M. (2016). Madrid bajo las bombas. Un análisis sectorial (Trabajo Fin de Máster). Universidad Complutense de Madrid, Madrid.

Navascués, P. (1984). El edificio de la Telefónica. Madrid, España: Espasa Calpe.

Quirós, F. et al. (2008): Madrid 1808. Guerra y territorio. Madrid, España: Ayuntamiento de Madrid.

Ribarevic-Nikolic, I. y Juric, Z. (1992). Mostar '92: Urbicid. Mostar, Bosnia y Herzegovina: Consejo Municipal de Defensa de Mostar.

Solé, J. M. y Villarroya, J. (2003). España en llamas. La Guerra Civil desde el aire. Madrid, España: Ediciones Temas de Hoy.

Uría, J. M. (2010). Vallecas bombardeada. Imágenes y documentos de la Guerra Civil (1936-1939). Recuperado de http://www.youblisher.com/p/1567928-Vallecas-bombardeada-Imagenes-ydocumentos-de-La-Guerra-Civil-1936-1939/ 